\title{
Rabbit and Mouse Models of HSV-1 Latency, Reactivation, and Recurrent Eye Diseases
}

\author{
Jody M. Webre, ${ }^{1}$ James M. Hill, ${ }^{1,2,3,4}$ Nicole M. Nolan, ${ }^{1,5}$ Christian Clement, ${ }^{1}$ \\ Harris E. McFerrin, ${ }^{6}$ Partha S. Bhattacharjee, ${ }^{1,6}$ Victor Hsia, ${ }^{7}$ Donna M. Neumann, ${ }^{1,2,8}$ \\ Timothy P. Foster, ${ }^{3}$ Walter J. Lukiw, ${ }^{1,4}$ and Hilary W. Thompson ${ }^{1,4,9}$
}

\author{
${ }^{1}$ Department of Ophthalmology, Louisiana State University Health Sciences Center (LSUHSC), New Orleans, \\ LA 70112, USA \\ ${ }^{2}$ Department of Pharmacology, Louisiana State University Health Sciences Center (LSUHSC), New Orleans, LA 70112, USA \\ ${ }^{3}$ Department of Microbiology, Louisiana State University Health Sciences Center (LSUHSC), New Orleans, LA 70112, USA \\ ${ }^{4}$ Neuroscience Center, Louisiana State University Health Sciences Center (LSUHSC), New Orleans, LA 70112, USA \\ ${ }^{5}$ College of Science and Engineering, Tulane University, New Orleans, LA 70118, USA \\ ${ }^{6}$ Department of Biology, Xavier University of Louisiana, One Drexel Drive, New Orleans, LA 70125, USA \\ ${ }^{7}$ School of Pharmacy and Health Professions, University of Maryland Eastern Shore, Princess Anne, MD 21853, USA \\ ${ }^{8}$ Department of Genetics, Louisiana State University Health Sciences Center (LSUHSC), New Orleans, LA 70112, USA \\ ${ }^{9}$ Department of Biostatistics, Louisiana State University Health Sciences Center School of Public Health, New Orleans, \\ LA 70112, USA
}

Correspondence should be addressed to Hilary W. Thompson, hthomp2@1suhsc.edu

Received 6 January 2012; Revised 4 May 2012; Accepted 22 May 2012

Academic Editor: Andre Van Wijnen

Copyright ( 2012 Jody M. Webre et al. This is an open access article distributed under the Creative Commons Attribution License, which permits unrestricted use, distribution, and reproduction in any medium, provided the original work is properly cited.

The exact mechanisms of HSV-1 establishment, maintenance, latency, reactivation, and also the courses of recurrent ocular infections remain a mystery. Comprehensive understanding of the HSV-1 disease process could lead to prevention of HSV-1 acute infection, reactivation, and more effective treatments of recurrent ocular disease. Animal models have been used for over sixty years to investigate our concepts and hypotheses of HSV-1 diseases. In this paper we present descriptions and examples of rabbit and mouse eye models of HSV-1 latency, reactivation, and recurrent diseases. We summarize studies in animal models of spontaneous and induced HSV-1 reactivation and recurrent disease. Numerous stimuli that induce reactivation in mice and rabbits are described, as well as factors that inhibit viral reactivation from latency. The key features, advantages, and disadvantages of the mouse and rabbit models in relation to the study of ocular HSV-1 are discussed. This paper is pertinent but not intended to be all inclusive. We will give examples of key papers that have reported novel discoveries related to the review topics.

\section{Introduction}

HSV-1 is remarkable in its ability to establish a lifelong latent infection in human hosts following exposure to the virus $[1,2]$. Numerous animal models have been used to study the phenomenon of HSV-1 latency, particularly in relation to the specific characteristics of virus strain and genetics, host response, and environmental factors. This paper will provide summaries and examples of latency, reactivation, inhibition of reactivation, and recurrent herpetic ocular lesions in rabbits and mice.
After initial infection, HSV-1 travels by retrograde axonal transport to sensory ganglia to establish latency. In this paper, we define latency as the retention of the quiescent viral genome in host neuronal tissue, with no demonstrable infectious virus present. Latency of HSV-1 occurs in the superior cervical ganglion (SCG) and trigeminal ganglion (TG), ciliary ganglion, nodose ganglion, otic ganglion, pterygopalatine ganglion, submandibular ganglion, geniculate ganglion $[1,3]$, ophthalmic branch of the trigeminal nerve, and root entry zone of the trigeminal nerve into the brainstem [4-6]. Latent HSV-1 has also been described 
in other nonneuronal tissues, such as the cornea [7]. Reactivation can occur spontaneously with virus strains known to be high phenotypic reactivators (HPRs), or after induction in latently infected animals [8-10]. Reactivation is identified by detection of HSV-1 DNA in tears and saliva and when infectious virus can be confirmed $[1,2]$. Recurrence is when HSV-specific corneal lesions are identified during latency. Recurrent lesions occur when HSV-1 is carried by anterograde transport to initial sites of infection or any site innervated by the latently infected ganglia and results in HSV-specific lesions followed by complications, such as stromal scarring, thinning, opacity, and neovascularization $[1,2]$.

\section{HSV-1 Strains}

Each HSV strain is defined as a clinical isolate that has been plaque purified and specifically identified in a publication. In addition to animal strain and gender, the strain of the virus can influence the susceptibility to infection by HSV1. HSV-1 strains such as McKrae and 17Syn+ have been found to exhibit a high rate of spontaneous shedding and are known as high phenotypic reactivators (HPRs) $[1,2,8]$. Low phenotypic reactivators (LPRs) exhibit a very low rate of spontaneous shedding and include F, KOS, SC-16, Rodanus, McIntyre, and CGA-3 $[1,2,8]$. One important viral recombinant LPR is LAT-negative $17 \Delta$ Pst recombinant, generated by deleting LAT promoter 17Syn+ (202 bp) [11]; because both viruses originate from the strain 17 background, they are useful in studying genotypic and phenotypic characteristics within a viral strain. Sawtell et al. [12] found that of the three HSV-1 strains commonly used, KOS, 17Syn+, and McKrae, KOS differs significantly in the capacity to reactivate from latency when induced in vivo. They reported that neurons in ganglia infected with HSV-1 strain KOS contained significantly fewer HSV-1 DNA copy numbers than those infected with 17Syn+ or McKrae [12]. In another report with HPR strains, a higher number of latent HSV-1 DNA copies were present in the individual neurons of ganglia, which overwhelm the cellular mechanisms that silence virus transcription and promote reactivation [13]. For example, strains 17 Syn+ and McKrae have been reported to establish more genome copies per neuron than KOS [14]. In one experiment, researchers used $\mathrm{W}$ strain cultured from a patient with typical HSV-1 dendritic keratitis and found that W strain is comparable to McKrae in its ease of induced reactivation and ocular shedding in rabbit and mouse models [15]. However, W strain is less neurovirulent than McKrae and therefore results in fewer cases of encephalitis and death [15].

The specific HSV-1 viral strain can make a significant difference in results and conclusions when studying HSV1 latency, reactivation, and recurrent disease. For example, Hill et al. [8] studied 10 groups of rabbits latently infected with various strains of HSV-1. Viruses used could be separated into four separate reactivation frequency groups: Macintyre and CGA-3 strains showed very low spontaneous and no induced reactivation. Strain SC16 showed modest spontaneous and induced reactivation. Rodanus, RE,
F, and KOS strains showed spontaneous reactivation but low induced reactivation in rabbits. HPR strains McKrae, 17 Syn+, and E-43 strains showed both spontaneous and induced reactivation $[8]$.

\section{Animal Species}

Mice and rabbits are used more than any other model to study HSV-1 latency, reactivation, and recurrence. Several characteristics make mouse models excellent candidates for studying HSV-1. In mice, inbred strains and transgenic strains are readily available, which has led to the widespread use of mouse models for studying ocular HSV-1. There are several thousand strains of transgenic mice, and most are named for the gene of interest which has been altered. The most common type of transgenic mouse used in the study of HSV-1 is the knockout mouse, where the activity of a single gene can be removed and its function analyzed. Table 1 summarizes reports of transgenic mice that have been used in the study of HSV-1 latency, reactivation, and recurrent disease. Many of the knockouts used for ocular herpes involved removing immune system components and are used for studying the immune system's effects on latency and reactivation. These transgenic mouse models have provided insight into the role of specific genes and cytokines involved in HSV-1 ocular disease.

Other advantages of the mouse model include its small size, which significantly reduces the amounts of drugs or chemicals needed for experiments. The low cost of boarding, as well as the relatively low cost of inbred strains, also contributes to the usefulness of mice. However, the disadvantages of mouse models primarily include the difficulty in assessing their corneal lesions and their small amounts of tissue recovered (harvested) for assays. The small tear film volume of mice decreases the efficiency of detecting infectious HSV-1 and HSV-1 DNA [1, 2, 16, 17]. The rate of spontaneous shedding of HSV-1 DNA in mice is extremely low, and there are no known reports of spontaneous recurrent lesions in immunocompetent mice.

The genetic makeup of the mouse influences susceptibility to HSV-1 latency, reactivation, and recurrent disease. Mice are available as noninbred or inbred (genetically homogenous) strains. Noninbred mice are less expensive and include the ICR, Swiss Webster, and NIH lines. Inbred strains of mice are used because of their genetic consistency and include C57BL/6 and BALB/c [17]. The strain of HSV-1, mouse strain, and mouse gender result in variability in the mortality, severity of infection, and frequency of reactivation $[1,2,16]$. For example, most strains of HSV-1 reactivate more readily in inbred $\mathrm{BALB} / \mathrm{c}$ mice than inbred $\mathrm{C} 57 \mathrm{BL} / 6$ mice, which is thought to be caused by differences in the host mouse immune system $[1,18,19]$.

Rabbits also have specific advantages and disadvantages as models for studying ocular HSV-1. Rabbits have larger eyes to examine and corneal lesions easily accessible for imaging and quantification by slit-lamp examination (SLE). Spontaneous lesions occur often in rabbits latent with HPR strains of HSV-1. Their large size provides more ocular and 
TABLE 1: Selected transgenic mice used for the study of ocular HSV-1.

\begin{tabular}{llr}
\hline Mouse name & Use of model & Author, year (reference no.) \\
\hline Rag2 $(-/-)$ & Study of ICP0 and ICP34.5 & Halford et al., 1996 [102] \\
Stat1 $(-/-)$ & IFN response to viral infection & Pasieka et al., 2011 [103] \\
INF $\alpha \beta \gamma$ R $(-/-)$ & IFN response to viral infection & Pasieka et al., 2011[103] \\
IRF-3 $(-/-)$ & Viral induction of type I INF cascade & Vitek et al., 2009 [104] \\
Human ApoE $4(+/+)$ & ApoE4 role in microglia immune response & Pasieka et al., 2008 [105] \\
Stat1 $(-/-)$ & Enhanced pathogenesis of Stat1 deficient mice & Bhattacharjee et al., 2008 [25] \\
Human ApoE3 $(+/+)$ & Human ApoE4 role in ocular herpes pathogenesis & Bhattacharjee et al., 2008 [25] \\
Human ApoE4 $(+/+)$ & Human ApoE4 role in ocular herpes pathogenesis & Kim et al., 2008 [106] \\
p19 $(-/-)$ & IL-23 role in the severity of HSV-1 ocular lesions & Lenschow et al., 2007 [107] \\
ISG15 $(-/-)$ & ISG15 role in host response to viral infection & Banerjee et al., 2007 [108] \\
Stat4 $(-/-)$ & Cytokine involvement in HSV-1 stromal keratitis events & Biswas et al., 2004 [109] \\
IL-1ra $(-/-)$ & IL-1 role in HSV-1 stromal keratitis & Halford et al., 2006 [110] \\
scid or rag2 $(-/-)$ & ICP0 role in viral replication & Haenchen et al., 2010 [111] \\
wt and p53 $(-/-)$ & Role of p43 in HSV-1 replication &
\end{tabular}

neural tissues for assessment, and their abundant tear film allows easy collection of tears. However, when compared to the mouse model, inbred strains of rabbits are very expensive and difficult to obtain. Because of their larger size compared to mice, purchasing and boarding expenses for rabbits lead to their much higher costs. Inoculation of rabbits with HPR strains results in 50\% mortality, and corneal inoculation with HPR strains results in stromal opacity in $5-10 \%$ of corneas $[1,2,16,20]$.

Rabbit strains that can be used for studies of ocular herpes include the New Zealand White (NZW), the Dutch Belted, and other pigmented rabbits. Rabbits with nonpigmented eyes (NZW) are the usual choice for vision research. Most strains of HSV-1 will infect any of the above rabbits, and their HSV-1 infection is more prototypical of human disease than that of mice [17]; rabbits latent with HPR strains have a high rate of spontaneous HSV-1 shedding, and their lesions share similar characteristics with human HSV-1 lesions [20].

Transgenic rabbits are very limited; however, researchers have obtained them for studying HSV-1. Chentoufi et al. [20] introduced a humanized HLA-A $* 0201$ transgenic rabbit model in their search for a vaccine against primary ocular herpes infection. The rabbit produces human HLA-restricted and specific T-cell responses for studying human CD8+ T-cell epitope-based vaccines. When this transgenic rabbit model is immunized with the vaccine, it produces HSV-1specific CD8 $\mathrm{T}$ cells and displays reduced $\mathrm{HSV}-1$ recurrent disease after induction from latent HSV-1 infection. Because the rabbit model is more similar to humans than to transgenic mice models previously used for this purpose, this transgenic rabbit could become an excellent animal model for studying these vaccines [20].

\section{Mice and HSV-1 Latency}

Mouse models have been used extensively to study HSV1 latency. Latency has been described molecularly as the

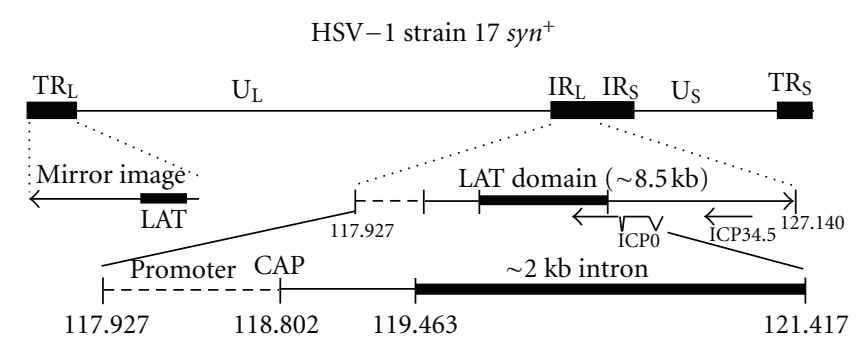

Figure 1: This figure depicts the linear HSV-1 strains 17 Syn+ noting specific regions of the genome. The abbreviations are as follows: $\mathrm{TR}_{\mathrm{L}}$-terminal repeat long; $\mathrm{TR}_{\mathrm{S}}$-terminal repeat short; $\mathrm{U}_{\mathrm{L}}$ - unique long; $\mathrm{U}_{\mathrm{S}}$ - unique short; $\mathrm{IR}_{\mathrm{L}}$-internal repeat long; $\mathrm{IR}_{\mathrm{S}}$ - internal repeat short. Note that LAT is in two regions of the HSV-1 genome $\left(\mathrm{TR}_{\mathrm{L}}\right.$ and $\left.\mathrm{IR}_{\mathrm{L}}\right)$. An $8.5 \mathrm{~kb}$ polyadenylated precursor is transcribed. Within the last domain are two very important immediate-early genes, ICP0 and ICP34.5. Also note the promoter, the CAP site, and a $2.0 \mathrm{~kb}$ intron. Further modification results in a $1.5 \mathrm{~kb}$ smaller intron.

state in which detectable viral gene expression is limited to the abundant transcription of LAT, a region of the HSV-1 genome that encodes an $8.5 \mathrm{~kb}$ polyadenylated RNA, which is then spliced into introns that accumulate in the nucleus (Figure 1) [1, 2, 21]. LAT is the only viral gene abundantly transcribed during HSV-1 neuronal latency [21, 22]. The full function of LAT remains a mystery, and mouse models have been used for years to investigate its purpose. Thompson and Sawtell [23] used a LAT-deletion mutant HSV-1 virus derived from a KOS/M parent in a murine model to show that the presence of LAT increases the number of neurons in which latency is established, but LAT has not been demonstrated to be required for establishment of latency [23]. In another mouse eye model, Thompson and Sawtell concluded that LAT promotes neuronal survival in latently infected TG [24].

Host genetic makeup also plays a role in establishment of HSV-1 latency. Studies of ApoE have found that this gene influences HSV-1 infections [25, 26]. Three major 
human alleles of the human ApoE gene code for six different isoforms of this glycosylated protein. The mouse has only one ApoE allele, which is suggested to be similar to one of the human isoforms, ApoE4. Several studies with mouse models have shown that human ApoE4 results in high neuroinvasiveness of HSV-1 [27-29]. Bhattacharjee et al. [29] studied ApoE4 with wild-type C57BL/6 mice and C57BL/6 knockout mice using corneal inoculation with HPR HSV-1 strain 17Syn+. They found that ApoE knockout mice are resistant to the neurovirulence of HSV-1 strain 17 Syn+, and the wild-type mouse had a higher latent load of virus in the TG than the knockout mice. The results showed that host ApoE genetics have a significant effect on establishment of HSV-1 latent infection in mice [29]. Furthermore, Burgos et al. [27] reported in their study of transgenic mice that their ApoE4 homozygote mouse had higher viral loads of HSV-1 in the midbrain, ventricles, cortex, and cerebellum than heterozygote or null mutants after hematogenous inoculation (intraperitoneal injection). The homozygote mice also had higher viral loads of HSV1 DNA in their TG and spinal cords, indicating that the amount of ApoE is directly linked to the invasiveness of HSV1 in the brain [27].

Mouse models have been used to study HSV-1 nonneuronal latency. This concept was first proposed by T. J. Hill et al. [30], who isolated infectious HSV-1 from $8 \%$ (7 of 88 ) of ears of latently infected, nonstimulated, noninbred mice. HSV-1 DNA has been found in corneas of patients with chronic herpetic keratitis and in eye bank corneas [7]. HSV1 could remain latent in corneas, but this has been difficult to confirm because of difficulty in proving that the virus remains latent in the cornea, rather than using the cornea as a transient site [7]. Mouse models have been used to study HSV-1 corneal shedding and the possibility of corneal latency. Abghari and Stulting [31] isolated HSV-1 from the eyes of latently infected mice and reported that infectious HSV-1 was detected earlier from TG cultures than corneal cultures. The results could suggest that the virus was latent in the cornea, because persistent viral shedding or persistent infections in the corneas would exhibit culture growth at a faster rate [31].

Mouse models provide evidence against HSV-1 corneal latency. Easty et al. [32] reported a study in which NIH mice were inoculated with HSV-1 in the cornea, and HSV-1 did not persist in the anterior segment. However, when mice were inoculated in the snout, infectious virus was detected in $40 \%(8 / 20)$ of corneas of noninbred latently infected mice [32]. These results suggested that either the sensory ganglion is required to establish latency, or the virus was actually reactivated from the ganglion [32]. Further study of corneal latency in animal models could lead to more efficient treatment of herpetic keratitis.

Most recently, mouse models have been used to study the role of T-cell exhaustion in controlling HSV-1 latency [3335]. For example, Allen et al. [33] studied the role of LAT in $\mathrm{CD} 8+\mathrm{T}$ cell exhaustion in the TG of mice latently infected mice. Reddy et al. [35] studied the TG in mice latently infected with HSV-1 and found that the Tim-3 (+) CD8 T cell interaction with ligand galectin- 9 could play a significant role in the outcome of $\mathrm{HSV}$-1 reactivation from latency. More research in these mouse models could set the stage for new therapeutic treatments to inhibit HSV-1 reactivation from latency.

4.1. Spontaneous HSV-1 Reactivation in Mice. Spontaneous reactivation of latent $\mathrm{HSV}-1$ has been shown to occur in humans [1, 36-39] and in experimentally infected rabbits $[1,2,8,40,41]$, but reports of spontaneous shedding in mice are limited (Table 2 ). This feature could provide an advantage over the rabbit model, as it decreases the potential complications that arise when experimentally induced shedding is difficult to dissociate from spontaneous shedding [42]. Many investigators have used the mouse model to study latent HSV-1, because they are able to assume that features of viral gene expression are attributable to latency, and not to spontaneous reactivation [43]. Many episodes of HSV-1 DNA shedding in humans are spontaneous, and it is believed that viral reactivation in the rabbit could be a more useful model for human disease for this reason [37]. However, latent mice that have been shown to spontaneously shed HSV-1 at low frequencies could indicate that experimental murine HSV-1 infection is similar to the infection in other animals and humans (see Table 2). For example, Margolis et al. provided evidence that latent mice exhibited spontaneous molecular reactivation occurring in very low frequency in their TG [16].

Table 2 represents data that demonstrate that spontaneous reactivation of $\mathrm{HSV}-1$ occurs in a very low percentage of noninduced latent mice. The table summarizes data of spontaneous shedding of HSV-1, and includes the gender and strain of mouse, HSV-1 strain, tissue studied, and frequencies of detection of infectious virus. Studies have suggested that the strain and gender of mice affect the frequency of HSV-1 reactivation [18]. Similarly, the viral strain of HSV-1 affects the latent viral load within ganglia, subsequently affecting the frequency of reactivation [12]. Regardless of the difference in parameters between studies shown in Table 2, the report of spontaneous reactivation of HSV-1 in mice exhibits frequencies of $3 \%$ (3/97) to $27 \%$ $(6 / 22)$. We conclude from these data that mice spontaneously shed HSV-1, but at frequencies lower than rabbits or humans.

Willey et al. [44] studied latently infected mice that had not been subjected to induced reactivation, and they showed that in $3 \%(3 / 97)$ of tear film swabs of the mice studied, HSV-1 infectious virus was detected. Productive cycle viral gene ICP-4 is expressed in a small number of latently infected murine TG in the absence of detectable infectious virus in their ganglia [43]. The study also noted that the neurons showing gene expression were surrounded by inflammatory cell infiltrates, suggesting recognition of the virus by the murine immune system [43]. Gebhardt et al. also showed the same immunorecognition in the rabbit eye model $[17,45]$.

Sawtell [46] developed an assay to quantify the number of neurons that were undergoing reactivation within murine TG during latency. Without induction, a greater percentage of HSV-1 protein-positive neurons undergoing spontaneous 
TABLE 2: Detection of infectious HSV-1 from eye swabs—-spontaneous shedding in noninduced mice.

\begin{tabular}{lccccc}
\hline Mouse strain & Gender & $\begin{array}{c}\text { HSV-1 } \\
\text { Strain }\end{array}$ & $\begin{array}{c}\text { Tissue/fluid/identification } \\
\text { procedure }\end{array}$ & $\begin{array}{c}\text { Frequency of detection of } \\
\text { reactivation }\end{array}$ & Authors, year (reference no.) \\
\hline BALB/c (inbred) & Male & McKrae & Ocular swabs & $3 / 97(3 \%)$ & $\begin{array}{c}\text { Willey et al., 1984 [44]; } \\
\text { Laycock et al., 1991 [112] }\end{array}$ \\
ICR (Harlem outbred) & Male & Patton & Explant TG & $6 / 22(27 \%) ; 14$ hr time period & Pesola et al., 2005 [113] \\
ICR (Harlem) & Male & KOS & Explant TG & $1 / 20(5 \%) ; 2$ hr time period & Pesola et al., 2005 [113] \\
ICR (Harlem) & Male & KOS & Explant TG & $4 / 18(22 \%) ; 14$ hr time period & Pesola et al., 2005 [113] \\
NIH-OLA (inbred) & NA & McKrae & Eye wash & $1 / 11(9 \%)$ & Shimeld et al., 1990 [42] \\
Swiss Webster (outbred) & Male & 17 Syn + & TG homogenized & $1 / 23(4 \%) ;$ PI day 31 & Sawtell 2003 [46] \\
Swiss Webster (outbred) & Male & 17 Syn + & TG homogenized & $1 / 16(6 \%) ;$ PI day 60 & Sawtell 2003 [46] \\
\hline
\end{tabular}

NA: not Available and PI: postinoculation.

reactivation were present at times most proximal to corneal inoculation. This suggests that the level of spontaneous reactivation decreases as the time postinoculation increases (Table 2) [46].

4.2. Mouse Ocular Models of Induced Reactivation. Studies of latency and reactivation are difficult to correlate in mice compared with humans, because different mouse strains have shown variable responses to different HSV-1 strains $[1,2,7,17,22]$. Studies have suggested that the mouse model of latency and reactivation in regard to LAT is mousestrain dependent (Figure 1) [22]. This is unlike the rabbit ocular model, in which LAT null mutants have exhibited consistently reduced reactivation in vivo [11, 47]. For example, LAT null mutants have been known to reactivate poorly in some mouse models, while some reports show that LAT null mutants show normal reactivation in other mouse phenotypes [22]. In one report, BALB/c and Swiss Webster mice were infected with LAT-negative or LAT-positive virus and were assessed by explant-induced reactivation of their TG. LAT-negative virus strains reactivated poorly in Swiss Webster mice, while the LAT-negative and LAT-positive strains showed no significant difference in reactivation frequencies in BALB/c mice [22]. The genetic component in $\mathrm{BALB} / \mathrm{c}$ mice that could account for this effect has not been determined.

There have been reports of LAT mutant experiments in mice that have different outcomes than similar experiments in rabbits. For example, Perng et al. [48] reported that the LAT regulation of $\mathrm{HSV}-1$ virulence and reactivation could be species specific. A LAT-negative transcript that showed a lower rate of reactivation in rabbits produced increased virulence in mice. Another LAT deletion transcript that had increased virulence in rabbits had decreased virulence in mice. This study suggests that LAT could have multiple functions, accounting for the different increases and decreases in virulence in the mouse and the rabbit [48]. The authors concluded that in addition to being involved in the HSV-1 latency and reactivation cycle, LAT also plays a role in neurovirulence. Murine latent HSV-1 infection following corneal inoculation has been induced to study reactivation with several stimuli, including heat stress, cyclophosphamide $(\mathrm{Cx})$ and dexamethasone (Dx), iontophoresis of epinephrine, and UVB. Table 3 cites reports of induced shedding in mice models, and the strain and gender of mouse, strain of virus, and method of induction are shown. There is evidence that mouse models can be used to induce HSV-1 shedding experimentally; the data show HSV1 detected in ocular swabs after induction over a range of 5\% $(1 / 20)$ to $100 \%(12 / 12)$. Willey et al. [44] used transcorneal iontophoresis of epinephrine to significantly increase the incidence of ocular HSV-1 shedding in the BALB/c mouse eye model. Shimeld et al. [42] used immunosuppressants followed by UVB in a murine model to induce viral replication and found that immunosuppression in combination with UVB produced a higher incidence of both shedding and recurrent disease compared to immunosuppression alone. In another experiment, Dx and Cx were used successfully for induction without UVB, to induce shedding without the ocular trauma that occurs with epinephrine iontophoresis or UVB exposure [49]. Intraperitoneal administration of sodium butyrate, a histone deacetylase inhibitor, has also been used successfully to induce HSV-1 shedding in mice. Neumann et al. [50] have used this induction method in their study of epigenetic changes within the HSV-1 associated chromatin during latency and reactivation. The method causes changes in histone acetylation of the LAT promoter region of HSV-1 in latent TG. Treatment with sodium butyrate consistently and reproducibly induces viral reactivation with HPR strains 17Syn+ and McKrae [51]. Clement et al. [52] used intraperitoneal administration of sodium butyrate in their study of epigenetic changes and host gene expression during reactivation from latency and reported multiple roles of the LAT-ICP0 locus in viral induction. Hyperthermia has been used in mice to induce HSV-1 shedding (see Table 3). Sawtell and Thompson [53] used Swiss Webster mice and reported that immersion in $42^{\circ} \mathrm{C}$ water induced reactivation of HSV-1 that occurred in neurons 14 hours after hyperthermic stress.

Furthermore, Clement et al. [54] have used hyperthermic stress in HSV-1 latently infected BALB/c mice to study host gene expression and reported upregulation of mainly immunity genes, indicating a role for the LAT-ICP0 locus in induction of the body's defense during viral reactivation from latency. 
TABLe 3: Detection of infectious HSV-1 from latent mice following stimulation.

\begin{tabular}{|c|c|c|c|c|c|c|c|}
\hline $\begin{array}{l}\text { Mouse } \\
\text { strain }\end{array}$ & Gender & $\begin{array}{l}\text { HSV-1 } \\
\text { strain }\end{array}$ & $\begin{array}{c}\text { Tissue/fluid/identification } \\
\text { procedure }\end{array}$ & $\begin{array}{l}\text { Frequency of } \\
\text { detection of } \\
\text { reactivation }\end{array}$ & $\begin{array}{l}\text { Type or method of } \\
\text { induction }\end{array}$ & Use of model & $\begin{array}{c}\text { Authors, year (reference } \\
\text { no.) }\end{array}$ \\
\hline $\begin{array}{l}\text { BALB/c } \\
\text { (inbred) }\end{array}$ & Male & McKrae & Eye swabs & $16 / 23(70 \%)$ & $\begin{array}{l}\text { Transcorneal } \\
\text { epinephrine } \\
\text { iontophoresis }\end{array}$ & Reactivation & Willey et al., 1984 [44] \\
\hline $\begin{array}{l}\text { NIH-OLA } \\
\text { (inbred) }\end{array}$ & NA & McKrae & Eye wash & $2 / 2(100 \%)$ & Immunosuppressant & $\begin{array}{l}\text { Reactivation } \\
\text { antigen studies }\end{array}$ & Shimeld et al., 1990 [42] \\
\hline $\begin{array}{l}\text { NIH-OLA } \\
\text { (inbred) }\end{array}$ & NA & McKrae & Eye wash & 9/9 (100\%) & $\begin{array}{c}\text { Immunosuppressant } \\
\text { UV-B }\end{array}$ & $\begin{array}{l}\text { Reactivation } \\
\text { antigen studies }\end{array}$ & Shimeld et al., 1990 [42] \\
\hline $\begin{array}{l}\text { NIH Swiss } \\
\text { Webster }\end{array}$ & Male & 17 Syn+ & Eye swab & $9 / 20(45 \%)$ & $\mathrm{Cx}$ and $\mathrm{Dx}$ & $\begin{array}{l}\text { LAT facilitates } \\
\text { reactivation }\end{array}$ & Cook et al., 1991 [49] \\
\hline $\begin{array}{l}\text { NIH Swiss } \\
\text { Webster }\end{array}$ & Male & $\begin{array}{l}\mathrm{XC}-20 \\
(\mathrm{LAT}+)\end{array}$ & Eye swab & $6 / 19(31.6 \%)$ & $\mathrm{Cx}$ and $\mathrm{Dx}$ & $\begin{array}{l}\text { LAT facilitates } \\
\text { reactivation }\end{array}$ & Cook et al., 1991 [49] \\
\hline $\begin{array}{l}\text { NIH Swiss } \\
\text { Webster }\end{array}$ & Male & $\begin{array}{l}\text { X10-13 } \\
\text { (LAT-) }\end{array}$ & Eye swab & $1 / 20(5 \%)$ & $\mathrm{Cx}$ and $\mathrm{Dx}$ & $\begin{array}{l}\text { LAT facilitates } \\
\text { reactivation }\end{array}$ & Cook et al., 1991[49] \\
\hline $\mathrm{BALB} / \mathrm{c}$ & Female & McKrae & Eye swab & $15 / 28(54 \%)$ & $\mathrm{NaB}$ in $\mathrm{PBS}$ & $\begin{array}{l}\text { In vivo HSV-1 } \\
\text { reactivation }\end{array}$ & $\begin{array}{l}\text { Neumann et al., } 2007 \\
{[51]}\end{array}$ \\
\hline $\mathrm{BALB} / \mathrm{c}$ & Female & 17 Syn+ & Eye swab & $21 / 65(32 \%)$ & $\mathrm{NaB}$ in $\mathrm{PBS}$ & $\begin{array}{l}\text { In vivo HSV-1 } \\
\text { reactivation }\end{array}$ & $\begin{array}{l}\text { Neumann et al., } 2007 \\
{[51]}\end{array}$ \\
\hline
\end{tabular}

Cx: cyclophosphamide, Dx: dexamethasone, LAT: latency-associated transcripts, NA: not available, NaB: sodium butyrate, and PBS: phosphate-balanced saline.

TABLE 4: Inhibition of induced HSV-1 reactivation in latent mice after stimulation.

\begin{tabular}{|c|c|c|c|c|c|c|c|}
\hline $\begin{array}{l}\text { Mouse } \\
\text { strain }\end{array}$ & Gender & $\begin{array}{l}\text { HSV-1 } \\
\text { strain }\end{array}$ & Inhibitor & $\begin{array}{c}\text { Frequency of } \\
\text { detection with } \\
\text { inhibitor }\end{array}$ & $\begin{array}{c}\text { Frequency of } \\
\text { detection } \\
\text { without } \\
\text { inhibitor }\end{array}$ & $\begin{array}{l}\text { Type or method of } \\
\text { induction }\end{array}$ & Authors, year (Reference no.) \\
\hline $\mathrm{BALB} / \mathrm{c}$ & NA & McKrae & Propranolol & $12 / 37(32 \%)$ & $20 / 31(65 \%)$ & Hyperthermia & $\begin{array}{c}\text { Gebhardt and Kaufman, } \\
1995[62]\end{array}$ \\
\hline $\mathrm{BALB} / \mathrm{c}$ & Female & McKrae & Anti-IL-6 antibodies & $6 / 20(30 \%)$ & $14 / 20(70 \%)$ & Hyperthermia & Kriesel et al., 1997 [114] \\
\hline $\mathrm{BALB} / \mathrm{c}$ & Female & McKrae & Anti-IL-6 antibodies & $2 / 20(20 \%)$ & $6 / 8(75 \%)$ & UVB & Kriesel et al., 1997 [114] \\
\hline $\mathrm{BALB} / \mathrm{c}$ & Female & McKrae & $\mathrm{ACV}$ & $20 / 50(40 \%)$ & $39 / 50(78 \%)$ & Hyperthermia & Gebhardt et al., 2004 [61] \\
\hline $\mathrm{BALB} / \mathrm{c}$ & NA & McKrae & ASA & $5 / 36(14 \%)$ & $11 / 36(31 \%)$ & Hyperthermia & Gebhardt et al., 2004 [56] \\
\hline $\mathrm{BALB} / \mathrm{c}$ & Female & McKrae & Celecoxib & $11 / 47(23 \%)$ & $28 / 52(54 \%)$ & Hyperthermia & Gebhardt et al., 2005 [115] \\
\hline $\mathrm{BALB} / \mathrm{c}$ & Female & McKrae & Bromfenac eye drops & $10 / 24(41.7 \%)$ & $16 / 22(72.2 \%)$ & Cx, Dx \& hyperthermia & Higaki et al., 2009 [58] \\
\hline $\mathrm{BALB} / \mathrm{c}$ & NA & W strain & Alpha blockers & $2 / 34(6 \%)$ & $10 / 39(29 \%)$ & Epinephrine iontophoresis & Gordon et al., 1990 [90] \\
\hline
\end{tabular}

ACV: acycloguanosine, ASA: aspirin, and NA: not available.

4.3. Inhibition of Reactivation in the Mouse Model as a Tool of Therapeutic Intervention Studies. Mouse models have been useful for studying the reduction of $\mathrm{HSV}-1$ reactivation (Table 4). The topical use of latanoprost in the treatment of glaucoma has been associated with viral reactivation and recurrence, and there have been reports of increased corneal epithelial lesions in humans and rabbits exposed to this prostaglandin analog [55]. These reports led to an interest in the role of prostaglandins in inducing HSV-1 reactivation [56]. Prostaglandins activate adenylate cyclase, which increases intracellular cAMP. Binding of cAMP to protein kinase A phosphorylates transcription factors, including the cAMP-responsive binding site of the LAT promoter region (Figure 1). Studies in mice have shown decreased reactivation of HSV-1 with mutations in the cAMP-responsive binding site [57].
The prostaglandin synthesis pathway is an intermediate pathway in the process of HSV-1 reactivation [56], and mouse models have been used to show that cyclooxygenase 2 inhibitors could be useful in the prevention of HSV-1 reactivation. Gebhardt et al. [56] reported that after hyperthermic stress, latently infected mice treated with celecoxib had less infectious virus on their ocular surfaces than controls (see Table 4). Higaki et al. [58] reported that bromfenac sodium eye drops significantly reduced HSV-1 ocular shedding in mice induced by immunosuppression and hyperthermia. They concluded that bromfenac sodium eye drops could be a potent medication for suppressing HSV-1 reactivation [58]. In another mouse study, acetylsalicylic acid, a nonspecific inhibitor of cyclooxygenase, reduced shedding of HSV-1 in the tears of induced mice. The authors concluded that acetylsalicylic acid suppressed viral reactivation in mice [56]. 
TABLE 5: Spontaneous shedding of infectious HSV-1 in latent rabbits.

\begin{tabular}{|c|c|c|c|}
\hline HSV-1 strain & Tissue/fluid/identification/procedure & Frequency of detection of reactivation & Authors, year (reference no.) \\
\hline Rodanus & Ocular swabs & $31 / 40(77 \%)$ between 31 and 100 days PI & Laibson and Kibrick,1969 [67] \\
\hline McKrae & Ocular swabs & $13 / 20(65 \%)$ & Nesburn et al., 1967 [68] \\
\hline McKrae & Ocular swabs & 19/20 (95\%) & Kwon et al., 1981 [9] \\
\hline McKrae & Ocular swabs & $2 / 10(20 \%)$ & Kwon et al., 1982 [73] \\
\hline McKrae & Ocular swabs & $3 / 20(15 \%)$ & Hill et al., 1983 [74] \\
\hline Rodanus & Ocular swabs & $1 / 3$ & Laibson and Kibrick,1966 [75] \\
\hline McKrae & Ocular swabs & $4 / 68(5.8 \%)$ & Hill et al., 1987 [81] \\
\hline McKrae & Ocular swabs & $6 / 140(4 \%)$ & Haruta et al., 1987 [10] \\
\hline McKrae & Ocular swabs & $28 / 216(13 \%)$ & Kaufman et al., 1996 [80] \\
\hline 17 Syn+ & Ocular swabs & $31 / 264(11.7 \%)$ & Kaufman et al., 1996 [80] \\
\hline McKrae & Ocular swabs & $10 / 610(1.6 \%)$ & Beyer et al., 1989 [83] \\
\hline McKrae & Ocular swabs & $4 / 14(29 \%)$ & Beyer et al., 1990 [84] \\
\hline W Strain & Ocular swabs & $11 / 16(69 \%)$ & Gordon et al., 2003 [15] \\
\hline McKrae & Ocular swabs & $14 / 20(70 \%)$ & Myles et al., 2003 [86] \\
\hline McKrae & Ocular swabs & $6 / 16(38 \%)$ & Hill et al., 1997 [87] \\
\hline McKrae & Ocular swabs & $13 / 20(65 \%)$ & Myles et al., 2004 [89] \\
\hline
\end{tabular}

Chronic oral administration of antiherpetics reduces the rate of ocular, genital, and oral recurrent lesions in humans $[1,2,37,59,60]$. Acycloguanosine (ACV) has been proven effective for preventing recurrent HSV-2 lesions of the genital and oral labia, in human and experimental models. Gebhardt et al. [61] found that ACV treatment significantly decreased the frequency of infectious HSV-1 virus in the ocular tear film and in the cornea of latently infected mice induced by hyperthermia. The mice did not, however, show any changes in HSV-1 DNA in their TG compared with controls. ACV was effective in decreasing viral replication in peripheral tissues, but is not effective in inhibiting viral reactivation and DNA synthesis in the peripheral nervous system [61].

Propranolol suppressed latent HSV-1 reactivation in mice, as data have shown that sympathomimetic amines, such as with epinephrine iontophoresis, modulate HSV-1 reactivation [44]. Propranolol suppressed shedding of HSV1 in murine models after hyperthermic stress [62]. This suggests that further study of the adrenergic pathway in HSV1 reactivation may illuminate cellular events involved in viral reactivation [62].

4.4. Recurrent Eye Disease in Mice. Mouse models have not been ideal for studying HSV-1 recurrent disease, because their small corneas are very difficult to assess. Studies of recurrent herpetic eye disease in mice are rare; however, there are some data which report HSV-1 recurrent disease in mice. Shimeld et al. [42] used SLE to assess recurrent disease in mice after $\mathrm{Cx}$ and Dx. Dendritic ulceration of mouse corneas was seen after induction in $13 \%(2 / 16)$ of latently infected mice [42].

\section{Rabbits}

5.1. Latency in Rabbits. Rabbits have been used for in vivo experiments with HSV-1 latency. Nesburn et al. [63] were among the first to show that HSV-1 remains latent in the TG between attacks of HSV-1 ocular disease in their experiment with NZW rabbits inoculated with McKrae. Rabbits, like mice, have been used to study the LAT gene's role in the establishment of latency (Figure 1). Bloom et al. [64] used rabbits to study the mutagenesis of a cAMP response element (CRE) within the LAT promoter region. NZW rabbits latently infected with a CRE recombinant virus derived from strain 17 Syn + showed reduced reactivation from latency after adrenergic stimulation. Perng et al. [65] also studied the role of the LAT gene in the establishment of latency in rabbits. They inserted the gene for enhanced green fluorescent protein (EGFP) under control of the LAT promoter in a LAT-negative and a LAT-positive virus. Then they examined the TG of the rabbits, and EGFP was detected in more LAT-positive infected neurons than LAT-negative infected neurons. Their results showed that LAT enhances the establishment of latency in the TG [65]. Clement et al. [66] reported active molecular response in the presence of the viral genome by microarray analysis of host gene expression for comparison between naïve and HSV-1 latent rabbit TG, suggesting equilibrium between the ability of the virus to reactivate and host suppression.

5.2. Spontaneous Reactivation in Rabbits. Rabbits can shed HSV-1 DNA in tears spontaneously if latent with an HPR HSV-1 strain. Rabbits latent with HPR also shed infectious virus and HSV-1 DNA in their tears at frequencies and copy numbers similar to humans $[1,2,8,17,38-41]$. Humans shed HSV-1 with almost $100 \%$ frequency over a 30 day observation period if latent with HSV-1 $[38,39]$. This common feature with humans makes the rabbit eye model a good candidate for HSV-1 research. Table 5 shows data from experiments that have shown up to $95 \%$ detection of spontaneous shedding in rabbits latently infected with HPR HSV-1 strains. 
Laibson and Kibrick [67] in 1969 reported spontaneous HSV-1 shedding in latently infected rabbits. They performed periodic examinations of NZW rabbits latently infected with the Rodanus strain of HSV-1, assessing for infectious virus and herpetic lesions. Over a three-year period after primary infection, they recorded 112 episodes of spontaneous viral reactivation in 50 rabbits. Corneal changes were observed $28 \%(31 / 112)$ of the time that virus was recovered [67]. Nesburn et al. [68] also showed that NZW rabbits latently infected with McKrae spontaneously shed; 65\% (13/20) of eyes spontaneously shed HSV-1 DNA in their tears, and 50\% (10/20) had lesions as seen by SLE. Kwon et al. [9] found that shedding of infectious virus (not stimulated) in control rabbits latently infected with McKrae was between 5\% and $10 \%$.

5.3. Induced Reactivation in HSV-1 Latent Rabbits. Although latently infected rabbits are known to shed HSV-1 spontaneously, stimuli given to rabbits latently infected with 17 Syn + or McKrae facilitates shedding more frequently and for longer durations (days) [1, 2, 69-72]. Experiments have shown that rabbits shed $100 \%$ of the time within 7 days post first stimuli $[1,2]$.

Rabbits have been used to study induction methods for HSV-1 reactivation from latency, much like mice. Table 6 shows examples of experiments that have induced reactivation in rabbits latently infected with HSV-1. Rabbits have been used to elucidate a model for adrenergic viral reactivation [9, 72-76]. Some of the first experiments showing induced reactivation of $\mathrm{HSV}-1$ in rabbits used electrical and mechanical stimulation of the TG $[77,78]$. Nesburn et al. [77] manually stimulated the TG of NZW rabbits latently infected with McKrae and reported that the direct trauma to the TG produced ocular HSV-1 shedding in $83 \%(10 / 12)$ of eyes [77]. Green et al. [79] used electrical current delivered to the TG to cause multiple episodes of reactivation in a single rabbit, a model well suited for antiviral testing.

Reports have shown that epinephrine iontophoresis induces HSV-1 shedding in latently infected rabbits reliably and with a high frequency (see Table 6). Hill et al. [72] examined the mechanism of epinephrine induction of HSV-1 reactivation by studying the effects of levo- and dextroepinephrine iontophoresis in rabbits. One hundred percent (5/5) of rabbits responded when administered higher doses of epinephrine. When rabbits were administered lower doses, D-epinephrine-induced ocular shedding was significantly less than L-epinephrine-induced shedding. From this rabbit model, the authors concluded that induction of HSV-1 ocular shedding by epinephrine is a stereoselective, receptormediated event that involves sympathetically innervated structures [72]. Shimomura et al. [71] also studied the mechanism of adrenergically induced HSV-1 reactivation from latency in rabbits. Iontophoresis of 6-HD, which causes degeneration of sympathetic nerve terminals in the anterior segment of the eye, enhanced the pharmacologic action of topical epinephrine for inducing ocular HSV-1 shedding [71]. 6-HD produces supersensitivity to adrenergic agonists; therefore, this experiment in the rabbit model confirms that adrenergic neural elements could act as a trigger for HSV-1 reactivation in latency [71].

\subsection{Rabbits as an Ocular Model for Therapeutic Intervention} Studies. Experiments with adrenergic inhibitors have also attempted to elucidate an adrenergic mechanism of HSV1 reactivation from latency. Systemic administration of the adrenergic inhibitor propranolol blocks spontaneous HSV1 ocular shedding and recurrent corneal disease in rabbits. Kaufman et al. [80] found that in NZW rabbits latently infected with $17 \mathrm{Syn}+$ or McKrae, propranolol reduced the amount of spontaneous HSV-1 shedding without any induced stressor. Paradoxically, Hill et al. [81] reported that timolol, an adrenergic antagonist, induced HSV-1 reactivation in latently infected rabbits super sensitized by 6-HD. Epinephrine, an adrenergic agonist, and timolol, an adrenergic antagonist, have the same effect of decreasing intraocular pressure, and it appears that they also have the same effect on induction of HSV-1 in latently infected rabbits [81]. Garza and Hill [82] studied the effect of propranolol on HSV-1 reactivation from latency (Table 7). The authors found that following either epinephrine iontophoresis or immunosuppression, systemic propranolol administration had no effect on $\mathrm{HSV}-1$ reactivation from latency as compared to systemic saline administration [82]. Because propranolol did not block HSV-1 induction in this rabbit model, researchers concluded that HSV-1 induction of reactivation in the rabbit may have a separate pathway from spontaneous reactivation [82]. Since rabbits spontaneously shed frequently when latent with a HPR HSV-1 strain, elucidating this mechanism could enhance the rabbit model of HSV-1 reactivation from latency.

Rabbit eye models have been used to study the effects of corneal manipulation of $\mathrm{HSV}-1$ reactivation from latency (Table 8). Procedures that damage the cornea, such as radial keratotomy (RK) and PKP, induce reactivation of HSV-1 in humans $[1,2,10]$. NZW rabbits latently infected with HSV$1 \mathrm{McKrae}$ strain had a statistically significant increase in the amount of infectious HSV-1 shedding and recurrent corneal lesions following RK [10]. The increased incidence of postPKP graft failure in those with HSV-1 keratitis was studied in rabbits by Beyer et al. [83]. NZW rabbits were infected with McKrae strain and underwent autograft PKP with or without Dx. In operated eyes without Dx, positive cultures were detected in 20\% (2/10) of the eyes; $82 \%$ (9/11) had positive cultures after PKP with Dx. There was a significantly greater incidence of superficial punctate keratitis (SPK) in eyes after PKP compared to unoperated eyes latently infected with HSV-1, and Dx significantly increased the incidence of SPK in operated eyes. Eyes treated with PKP and Dx had a significantly increased incidence of stromal keratitis compared with unoperated eyes and eyes after PKP without Dx treatment. The authors concluded that PKP and Dx induce HSV-1 reactivation and recurrent disease in latently infected rabbits, providing a useful tool for studying the development and treatment of recurrent HSV-1 after PKP [83]. Beyer et al. [84] showed that manipulation of corneal nerves induces HSV-1 reactivation in latently infected rabbits. They used cryogenic 


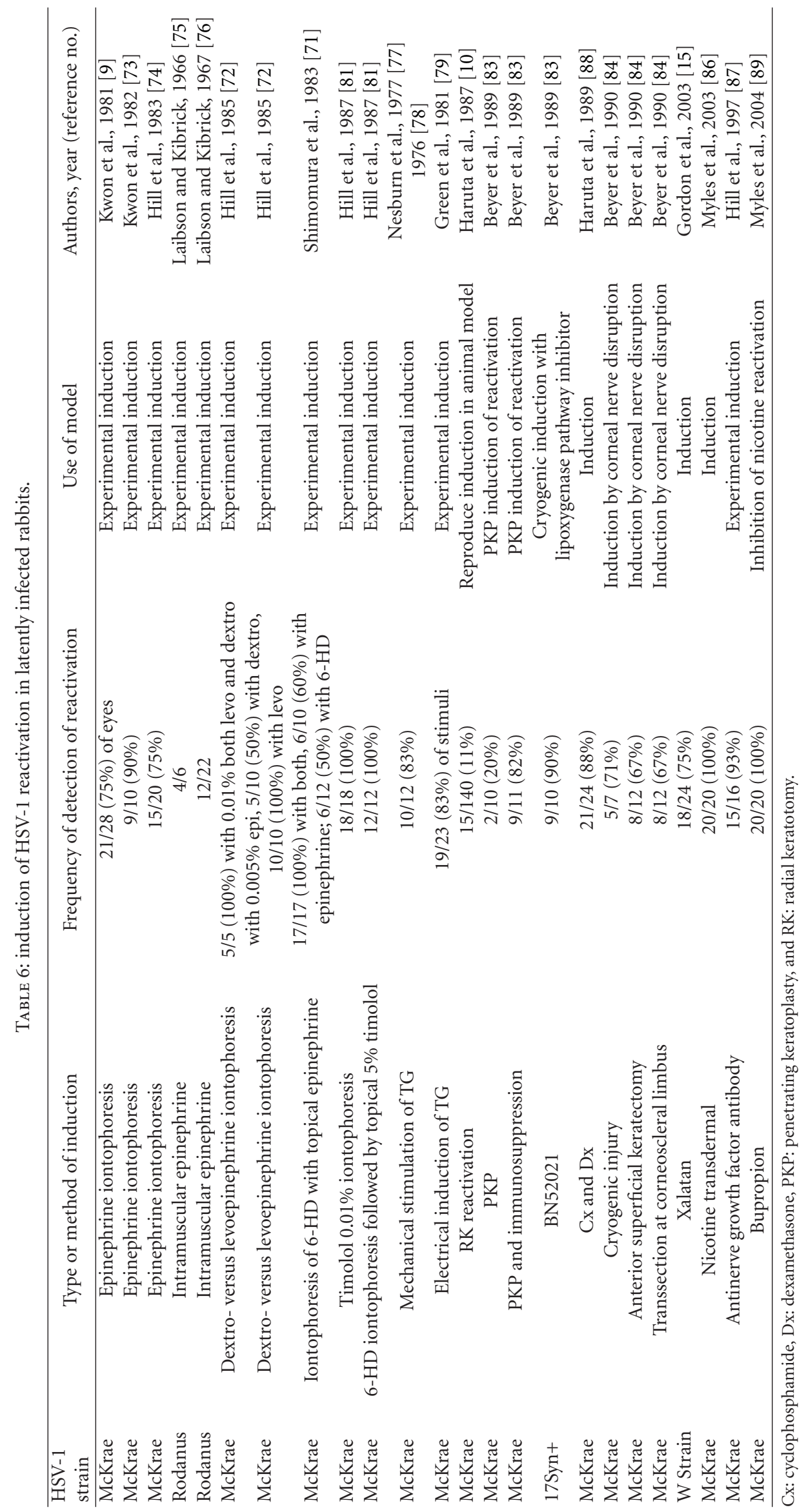


TABLE 7: Inhibitor of HSV-1 reactivation in latently infected rabbits.

\begin{tabular}{|c|c|c|c|c|}
\hline $\begin{array}{l}\text { HSV-1 } \\
\text { Strain }\end{array}$ & Inhibitor & $\begin{array}{l}\text { Frequency of detection of } \\
\text { reactivation with inhibitor }\end{array}$ & $\begin{array}{l}\text { Frequency of detection of } \\
\text { reactivation without inhibitor }\end{array}$ & Authors, year (reference no.) \\
\hline McKrae & $\begin{array}{l}\text { Propranolol with } \\
\text { epinephrine iontophoresis }\end{array}$ & $\begin{array}{l}56 / 84(67 \%) \text { with } 20 \mathrm{mg} / \mathrm{kg} \text {; } \\
23 / 42(55 \%) \text { with } 200 \mathrm{mg} / \mathrm{kb}\end{array}$ & $46 / 84(55 \%)$ and $20 / 42(48 \%)$ & Garza and Hill, 1997 [82] \\
\hline McKrae & Propranolol with Cx and Dx & $27 / 56(48 \%)$ & $29 / 63(46 \%)$ & Garza and Hill, 1997 [82] \\
\hline 17 Syn+ & $\begin{array}{l}\text { Propranolol with } \\
\text { epinephrine iontophoresis }\end{array}$ & $\begin{array}{c}43 / 70(61 \%) \text { with } 5 \mathrm{mg} / \mathrm{kg} ; 29 / 56 \\
\text { (52\%) with } 200 \mathrm{mg} / \mathrm{kg}\end{array}$ & $34 / 70(49 \%)$ and $7 / 8(88 \%)$ & Garza and Hill, 1997 [82] \\
\hline 17 Syn+ & Propranolol with Cx and Dx & $24 / 63(38 \%)$ & $21 / 56(38 \%)$ & Garza and Hill, 1997 [82] \\
\hline McKrae & Propranolol & $20 / 264(7.6 \%)$ & $28 / 216(13 \%)$ & Kaufman et al., 1996 [80] \\
\hline 17 Syn+ & Propranolol & $11 / 336(3.3 \%)$ & $31 / 264(11.7 \%)$ & Kaufman et al., 1996 [80] \\
\hline McKrae & Bupropion & $9 / 20(45 \%)$ & $13 / 29(65 \%)$ & Myles et al., 2004 [89] \\
\hline McKrae & $\begin{array}{l}\text { Bupropion with nicotine } \\
\text { transdermal }\end{array}$ & $13 / 36(36.1 \%)$ & $35 / 36(97.2 \%)$ & Myles et al., 2004 [89] \\
\hline W strain & Alpha blockers & $10 / 14(71 \%)$ & $13 / 14(93 \%)$ & Gordon et al., 1990 [90] \\
\hline
\end{tabular}

Cx: cyclophosphamide and Dx: dexamethasone.

TABLE 8: Induced recurrent corneal lesions in HSV-1 latently infected rabbits.

\begin{tabular}{|c|c|c|c|}
\hline $\begin{array}{l}\text { HSV-1 } \\
\text { strain }\end{array}$ & Frequency of detection of reactivation & Type or method of induction & Authors/year (reference no.) \\
\hline McKrae & $\begin{array}{c}\text { 9/10 (90\%) SPK; } 1 / 10 \text { (10\%) dendrites; } 9 \\
\text { epithelial ulcers }\end{array}$ & PKP & Beyer et al., 1989 [83] \\
\hline McKrae & $\begin{array}{c}\text { 11/11 (100\%) SPK; } 1 / 11 \text { (9\%) dendrites; 9/11 } \\
\text { (82\%) epithelial ulcers }\end{array}$ & PKP plus Dx (immunosuppressant) & Beyer et al., 1989 [83] \\
\hline 17 Syn+ & $5 / 10(50 \%) ; 2 / 10(20 \%)$ of controls & BN 52021 & Beyer et al., 1989 [85] \\
\hline McKrae & $36 / 157(23 \%)$ & $\begin{array}{l}0.1 \% \text { 6-HD iontophoresis followed by } \\
\text { topical } 0.1 \% \text { Propine }\end{array}$ & Hill et al., 1987 [116] \\
\hline McKrae & $20 / 24(83 \%)$ & $C x$ and $D x$ & Haruta et al., 1989 [88] \\
\hline McKrae & $17 / 34(50 \%)$ & $0.01 \%$ timolol iontophoresis & Haruta et al., 1987 [10] \\
\hline McKrae & $7 / 12(58 \%)$ & $\begin{array}{l}\text { transsection at corneoscleral limbus } \\
\text { (corneal nerve disruption) }\end{array}$ & Beyer et al., 1990 [84] \\
\hline
\end{tabular}

Rabbits were inoculated in the eye. Lesions were identified using slit-lamp examination. Cx: cyclophosphamide, Dx: dexamethasone, PKP: penetrating keratoplasty, and SPK: superficial punctate keratitis.

injury, anterior superficial keratectomy, and transsection of the corneal nerves at the corneoscleral limbus to induce corneal injury. Significantly more HSV-1 infectious virus was shed after corneal disruption than in controls. Corneal nerve damage induced HSV-1 reactivation from latency [85].

Several experiments have used compounds that enhance the stress response to induce HSV-1 shedding in latently infected rabbits (see Table 7). Myles et al. [86] used nicotine, a compound known to be involved in stress-associated immunomodulation, to induce HSV-1 reactivation in rabbits latently infected with HSV-1 strain McKrae. Transdermal nicotine application to latently infected rabbits yielded $100 \%$ (20/20 eyes) ocular shedding as compared with controls in which $70 \%$ (14/20 eyes) had spontaneous shedding. The authors hypothesized that nicotine induces HSV-1 reactivation in the rabbit eye model because of its ability to modulate peripheral endocrine and central neuroendocrine receptors in the animal [86]. Nicotine induces HSV-1 reactivation most likely by initiating the stress response, releasing epinephrine and norepinephrine from the adrenal medulla. Hill et al. [87] also found a novel approach to inducing the stress response using antinerve growth factor (NGF) antibody to induce HSV-1 reactivation from latently infected rabbits. NGF, required for survival and differentiation of sympathetic and sensory neurons, is involved in the physiological homeostasis of adult differentiated neurons. It is thought to share a common second messenger pathway with heat or cold stress-induced reactivation of latent HSV1. In this experiment, researchers found that rabbits treated with anti-NGF antibody had HSV-1 shedding in 93\% (15/16) of eyes, as compared to controls with $38 \%$ (6/16) of eyes spontaneously shedding [87].

Lipoxygenase products and inflammatory pathway inhibitors have been studied as factors involved in HSV1 reactivation in latently infected rabbits. Beyer et al. [85] administered BN52021, a platelet-activating factor antagonist, to latently infected rabbits and analyzed reactivation after cryogenic-induced lesions. Rabbits given the antagonist had significantly more positive cultures than controls, and geographic ulcers persisted for a longer amount of time in the affected group than in controls. This method of induction is similar to that of steroids and 
NSAIDs in its inhibition of arachidonic acid metabolism [85]. Haruta et al. [88] showed that immunosuppression with $\mathrm{Cx}$ and Dx induced HSV-1 shedding and produced recurrent corneal epithelial lesions characteristic of HSV-1 in rabbits, without compromising the structural integrity of the corneal epithelium. Therefore, $\mathrm{Cx}$ and $\mathrm{Dx}$ are ideal immunosuppressants for experiments investigating recurrent HSV-1 corneal lesions.

In glaucoma patients treated with Xalatan $(0.005 \%$ latanoprost, Pharmacia Corp., Peapack, NJ, USA), there is an increased incidence of recurrent herpetic ulcers [15]. Gordon et al. [15] used this concept in rabbits to study the effects of Xalatan on spontaneous shedding and induction from rabbits latently infected with HSV-1. Xalatan or its separate individual components were administered to latently infected rabbits, and intrastromal injection of sterile deionized water was used for induction. The results of the experiment showed that neither Xalatan nor its individual components caused an alteration in induced HSV1 shedding in latently infected rabbits when compared with untreated controls. There were also no significant differences between Xalatan-treated and control groups when rabbits were evaluated for spontaneous shedding.

5.5. Inhibition of Induction in Rabbits. Rabbits have been used to study methods of preventing HSV-1 reactivation from latent infection. Table 7 reports examples of methods that have shown decreased reactivation after induction from HSV-1 in latently infected rabbits. There is anecdotal evidence suggesting that patients taking bupropion (ZybanSR, GlaxoSmithKline, Greenville, NC, USA), an atypical antidepressant used for smoking cessation, have a decreased incidence of HSV-1 recurrent disease. The mechanism of action of bupropion involves inhibition of norepinephrine, serotonin, and dopamine neuronal uptake. This decreased level of neurotransmitters, especially norepinephrine, is thought to account for the decrease in spontaneous recurrence of HSV-1 lesions in patients using bupropion. Myles et al. [89] used NZW rabbits latently infected with McKrae to show that bupropion inhibits nicotine-induced shedding of ocular HSV-1 in vivo, and bupropion alone inhibits HSV-1 shedding compared to controls.

Kaufman et al. [80] reported propranolol suppression of HSV-1 reactivation from latently infected rabbits. Their results showed reduced reactivation of rabbits latently infected with HSV-1 as evidenced by the decreased amount of time that herpetic lesions were present, the decreased frequency of viral shedding, and the decreased number of episodes per eye in rabbits treated with propranolol as compared with controls (see Table 7).

Gordon et al. [90] reported the effect of alpha blockers, thymoxamine, and corynanthine, on HSV-1 reactivation in latently infected rabbits and mice. Their results contributed to the hypothesis that host differences play a key role in the process of HSV-1 reactivation from latency. When comparing the effects of alpha blockade on HSV-1 W strain reactivation from latency after epinephrine iontophoresis, the researchers found significantly less reactivation in treated
$\mathrm{BALB} / \mathrm{c}$ mice, but no statistically significant difference in reactivation of treated NZW rabbits from controls [90]. This experiment suggests a complex difference in the pharmacologically mediated HSV-1 reactivation process between mice and rabbits. The exact mechanism to explain this difference has yet to be discovered.

5.6. Recurrent HSV-Specific Corneal Lesions in Rabbits. While mice are useful for the study of HSV-1 induction and reactivation from latency, they are not as appropriate an animal model for studying patterns of recurrent HSV-1 specific ocular lesions and complications. Rabbits, however, have been an extremely useful animal model for studying HSV-1 recurrent ocular lesions. Several methods have been used to induce herpetic corneal lesions in rabbits $[80,83-$ $85,88]$. Recurrent herpetic eye disease in rabbits is much easier to assess than in mice, because they are better suited for SLE. Table 8 shows data from experiments which recorded increased herpetic corneal lesions when rabbits latent with HSV-1 were induced.

Induction of HSV-1 corneal lesions has been accomplished by both adrenergic iontophoresis and immunosuppression, which both yield deep punctuate, dendritic, and geographic corneal epithelial lesions [91]. For example, Haruta et al. [88] documented corneal lesions in eyes of NZW rabbits latently infected with McKrae after induction with $C x$ and Dx. The ratio of positive days of epithelial lesions per total days was $44 \%(82 / 187)$. The lesions were correlated with the number of positive swabs recorded during the experiment, confirming that $\mathrm{Cx}$ and Dx induce HSV-1 shedding and corneal epithelial lesions in rabbits latently infected with McKrae [88]. Beyer et al. [83] found that PKP induces the recurrence of epithelial lesions in NZW rabbits latently infected with McKrae. Kaufman et al. [80] reported that propranolol suppressed the frequency HSV-1 corneal lesion recurrence after hyperthermic stress of rabbits latently infected with $17 \mathrm{Syn}+$ or McKrae as compared to controls (Table 9).

\section{Statistical Analysis of Ocular HSV-1 Data}

This section will examine and explain some methods of statistical analyses that deal with quantification of viral particles or viral DNA, where viral DNA copy numbers are taken as surrogate variables for viral copy numbers. The importance of gene expression data, immunological function, and so forth, is great. In this section, we focus on statistical methods appropriate for quantification of viral particles and HSV-1 copy numbers as experimental outcomes in many of the reviewed animal models in HSV1 eye disease.

Statistical methods in the biomedical literature, when surveyed by statisticians, are often found to be inadequate. Such shortcomings of statistical technique have also been noted in the literature of virology [92]. More uniform statistical methods applied in animal models of HSV-1 eye disease will facilitate meta-analytic studies attempting summarization of results from many studies conducted over 
TABLE 9: Reagents or methods that can inhibit or induce HSV-1 reactivation for rabbits and mice.

\begin{tabular}{|c|c|c|c|}
\hline Reagents or methods & $\begin{array}{l}\text { Mice latently infected with } \\
\text { HSV-1 }\end{array}$ & $\begin{array}{l}\text { Rabbits latently infected } \\
\text { with HSV-1 }\end{array}$ & Reference(s) \\
\hline Epinephrine iontophoresis & Induces $[44]$ & Induces $[9,72-74,90]$ & $\begin{array}{c}\text { Willey et al., } 1984 \text { [44] } \\
\text { Gordon et al., } 1990 \text { [90] } \\
\text { Kwon et al., } 1981 \text { [9] } \\
\text { Kwon et al., } 1982[73] \\
\text { Hill et al., } 1983 \text { [74] } \\
\text { Hill et al., } 1985 \text { [72] }\end{array}$ \\
\hline UV-B & Induces $[42,114]$ & & $\begin{array}{l}\text { Shimeld et al., } 1990 \text { [42] } \\
\text { Kriesel et al., } 1997 \text { [114] }\end{array}$ \\
\hline $\mathrm{Cx}$ and $\mathrm{Dx}$ & Induces $[49,58]$ & Induces $[88]$ & $\begin{array}{l}\text { Cook et al., } 1991[49], \\
\text { Higaki et al., } 2009 \text { [58], } \\
\text { Haruta et al., } 1989 \text { [10] } \\
\text { Haruta et al., } 1989 \text { [88] }\end{array}$ \\
\hline $\mathrm{NaB}$ in $\mathrm{PBS}$ & Induces [51] & & Neumann et al., 2007 [51] \\
\hline Hyperthermia & $\begin{array}{c}\text { Induces } \\
{[56,58,61,62,114,115]}\end{array}$ & & $\begin{array}{c}\text { Gebhardt and Kaufman, } 1995 \\
\text { [62] } \\
\text { Kriesel et al., } 1997 \text { [114] } \\
\text { Gebhardt et al., } 2004 \text { [61] } \\
\text { Gebhardt et al., } 2004 \text { [56] } \\
\text { Gebhardt et al., } 2005 \text { [115] } \\
\text { Higaki et al., } 2009 \text { [58] }\end{array}$ \\
\hline Propranolol & Inhibits [62] & Inhibits $[80]$ & $\begin{array}{c}\text { Gebhardt and Kaufman, } 1995 \\
{[62]} \\
\text { Kaufman et al., } 1996[80]\end{array}$ \\
\hline Anti-IL-6 antibodies & Inhibits [114] & & Kriesel et al., 1997 [114] \\
\hline ASA & Inhibits [115] & & Gebhardt et al., 2004 [56] \\
\hline Celecoxib & Inhibits [115] & & Gebhardt et al., 2005 [115] \\
\hline Bromfenac & Inhibits [58] & & Higaki et al., 2009 [58] \\
\hline Alpha blockers & Inhibits [90] & & Gordon et al., 1990 [90] \\
\hline 6-HD iontophoresis & & Induces [81] & Hill et al., 1987 [81] \\
\hline Timolol & & Induces $[81,117]$ & $\begin{array}{c}\text { Hill et al., } 1987 \text { [81] } \\
\text { Haruta et al., } 1988 \text { [117] }\end{array}$ \\
\hline Mechanical stimulation of TG & & Induces [77] & Nesburn et al., 1977 [77] \\
\hline Electrical stimulation of TG & & Induces [79] & Green et al., 1981 [79] \\
\hline PKP & & Induces [83] & Beyer et al., 1989 [83] \\
\hline Platelet activating factor antagonist & & Induces $[85]$ & Beyer et al., 1989 [85] \\
\hline Cryogenic injury & & Induces $[84]$ & Beyer et al., 1990 [84] \\
\hline Anterior superficial keratectomy & & Induces $[84]$ & Beyer et al., 1990 [84] \\
\hline Transsection at corneoscleral limbus & & Induces [84] & Beyer et al., 1990 [84] \\
\hline Xalatan & & Induces [15] & Gordon et al., 2003 [15] \\
\hline Nicotine transdermal & & Induces $[86]$ & Myles et al., 2003 [86] \\
\hline Antinerve growth factor antibody & & Induces [87] & Hill et al., 1997 [87] \\
\hline Bupropion & & Inhibits [89] & Myles et al., 2004 [89] \\
\hline
\end{tabular}

years of research, funding, and publication. Eventually, such uniformity of practice will result in greater value of the combined efforts of many research groups over years of effort and, perhaps, even using different animal models of HSV-1 eye disease. Thus, while our comments on statistical methods in HSV-1 disease models will of necessity be a brief section of a review, our hope is this will provide a guide that will lead investigators to consider these fundamental aspects of statistical design and analysis more closely and perhaps to seek statistical consultation on these often difficult methodological problems prior to experimental design or statistical analysis.

Perhaps most important among the statistical issues in analysis of viral counts (obtained by whatever means) is that analysis of frequencies or count data must be addressed using a body of statistical methods known as categorical models, 
or methods for the analysis of frequencies [93]. In some cases, count data may contain large count values and may be analyzed as if the count variable was a continuous variable. In contrast, relatively small sample sizes and sparse data which could include zeros, as well as truncated distributions often characteristic of count data, make this naïve assumptionthat discrete variables act like continuous variables-a potential cause of problems for statistical estimation and hypothesis testing. Variables used as outcomes in mouse and rabbit models of HSV-1 eye disease may also represent ordinal or nominal scores as well as count data. One such example is an investigator-tallied score for corneal involvement with HSV-1 lesions or a scoring of the severity of associated pathological characteristics such as amount of pus or inflammation. Different statistical methods are appropriate for these different outcome variable types.

Often an additional level of complexity in HSV-1 animal models is observation over time. Experimenters may be concerned with the detailed dynamics of a disease process over time in addition to treatment averages at the end of a period of observation. This adds complexities related to correlations found among observations coming from one experimental subject over time (called within subject correlations). If these correlations within subjects are not dealt with correctly in the experimental design and analysis, they can inflate the test statistics and distort the conclusions of the statistical analysis. The dynamics of the infectious process may be the most important aspect of the HSV1 animal model, and changes over time must be properly modeled and evaluated statistically. Time series or so-called "repeated measures models" represent an additional level of complexity where outcomes are frequencies.

One assumption which underlies the correct application of parametric statistical methods such as the analysis of variance (ANOVA) is an assumption concerning the normal distribution. This assumption is frequently a source of confusion for nonstatistically trained consumers of statistical analyses. It is not the distribution of the values of the variables under analysis that this assumption addresses; thus the frequently mentioned (erroneous) idea that if values of a variable are not normally distributed, parametric methods cannot be applied, and discrete or nonparametric methods must be used. It is rather the distribution of the means of samples of a variable that we expect to be normally distributed, and this is the assumption our application of parametric methods requires. This approach to the normal distribution of the means of samples from a random variable is addressed in statistical theory by the central limit theorem [94]. This theorem provides that the means of samples from any distribution (normal or not) will approach the normal distribution in the long run with repeated sampling. Parametric methods such as the $t$-test or ANOVA will perform in a reliable manner if the assumption of normality is violated or not. These tests exhibit a property of statistical methods called robustness.

The assumption of the equality of the variance of each sampled population causes more substantial problems with the performance of statistical estimators. Violation of this assumption causes us to turn to categorical or nonparametric methods rather than the normal distribution of sample means. Means from samples which include varying numbers of high counts or zeros are likely to be unequal in variance. This situation is typical in counting herpetic lesions or in counts of viral particles and is characteristic of processes that are Poisson distributed or distributed in accord with other random discrete distributions.

Simple chi-square tests of a basic kind taught in statistics 101 courses are useful when viral counts are compared between treatments without time observations. A more conservative alternative is the use of exact versions of contingency table tests. These originated in the Fisher's exact test, which was originally applied to $2 \times 2$ contingency tables [95], but have been extended to $n \times n$ contingency tables in the modern era of cheap computational power [96]. Power analyses for such experiments and considerations of subdividing the effects which account for overall significance have been described in basic nontechnical terms $[97,98]$.

Perhaps more useful but more challenging are analytic methods applying generalized linear models [99]. Here the analyst has much greater flexibility to model multiple simultaneous experimental effects such as treatments and their effects over time, as well as to control for "nuisance variables" such as groups or litters of animals. Many different "link" functions can be applied in such models, providing linear additive models type treatment of essentially nonlinear response functions. Extensions of generalized linear models have been developed and are widely applied to observations of subjects over multiple time periods, such as are those often obtained in animal experiments where individual animals are assessed at multiple time points [100].

Many responses are nonlinear, such as the responses that are often seen in pharmacological experiments, or survival data where observations may be incomplete at the conclusion of the experiment (censored observations). In these cases, modern methods of analysis that specifically deal with nonlinear responses allow analysts flexibility to deal with random and fixed effects in the same models of animal testing [101]. More ability to deal with the complexities of experimental design increases the demands for the expertise of the analyst, as more parameters must be assessed and determined and more diagnostics conducted to assess model fitness. As is said in statistical consulting, "what must be taught to clients is not how to do statistics, but when to ask for a statistical consultant."

\section{Summary}

This paper provides information and examples of animal models of ocular HSV-1 latency, reactivation, and recurrent disease. Both rabbit and mouse eye models have been successful for studying ocular HSV-1, and each model resulted in new information and discoveries related to human HSV-1 ocular disease. The rabbit eye model has been especially important for investigating viral reactivation and recurrent ocular disease. The mouse model has been useful for studying latency, reactivation, and genetics involved with ocular HSV-1. 
Though HSV-1 latency, reactivation, and recurrent disease are not fully understood and the mechanisms are still unknown, therapy for HSV-1 recurrent disease has improved significantly since the first antiherpetic was used successfully in 1962. Continued improvement will likely occur through combination therapy as investigators continue to do research. Also, a better understanding of host and viral genetics should allow improved clinical management of recurrent ocular HSV-1, especially herpetic stromal diseases. Mice and rabbit eye models will continue to play a critical role in this important vision research.

\section{Abbreviations}

$\begin{array}{ll}\text { ACV: } & \text { Acyclovir } \\ \text { ApoE: } & \text { Apolipoprotein E } \\ \text { ASA: } & \text { Aspirin } \\ \text { Cx: } & \text { Cyclophosphamide } \\ \text { Dx: } & \text { Dexamethasone } \\ \text { HPR: } & \text { High phenotypic reactivator } \\ \text { HSK: } & \text { Herpes stromal keratitis } \\ \text { HSV-1: } & \text { Herpes simplex virus type 1 } \\ \text { IL-6: } & \text { Interleukin 6 } \\ \text { INF: } & \text { Interferon } \\ \text { LAT: } & \text { Latency-associated transcripts } \\ \text { LPR: } & \text { Low phenotypic reactivator } \\ \text { NGF: } & \text { Nerve growth factor } \\ \text { NZW: } & \text { New Zealand White } \\ \text { PKP: } & \text { Penetrating keratoplasty } \\ \text { PTG: } & \text { Pterygopalatine ganglion } \\ \text { RK: } & \text { Radial keratotomy } \\ \text { SCG: } & \text { Superior cervical ganglion } \\ \text { SLE: } & \text { Slit-lamp exam } \\ \text { SPK: } & \text { Superficial punctate keratitis } \\ \text { TG: } & \text { Trigeminal ganglion } \\ \text { UVA, UVB: Ultraviolet. }\end{array}$

\section{Conflict of Interests}

None of the authors has a proprietary interest in anything mentioned in this article.

\section{Acknowledgments}

This work was supported in part by funding from the National Institutes of Health, National Eye Institute grants R01-EY006311 (J. M. Hill), R01-EY14289 (J. M. Hill), R21EY019144 (P. S. Bhattacharjee), R15-EY020803 (V. Hsia); the $\mathrm{NIH}$ National Institute on Aging AG18031 and AG038834 (W. J. Lukiw), AG23085 (J. M. Hill); Grant P20RR016456 from the National Center for Research Resources (H. E. McFerrin). The content is solely the responsibility of the authors and does not necessarily represent the official views of the National Eye Institute, National Institute on Aging, the National Center for Research Resources, or the National Institutes of Health. The work was also supported by an unrestricted research grant from the LSU Health Sciences Center (J. M. Hill); Transitional Research Initiative grants
(W. J. Lukiw); a research grant from LSUHSC (D. M. Neumann); a Research to Prevent Blindness (RPB) Senior Scientific Investigator Award (J. M. Hill); an unrestricted grant to the LSU Eye Center from RPB, New York, NY, USA; the Louisiana Biotechnology Research Network (W. J. Lukiw, and J. M. Hill); an Alzheimer Association InvestigatorInitiated Research Grant IIRG-09-131729 (W. J. Lukiw); the Xavier University of Louisiana Center for Undergraduate Research (P. S. Bhattacharjee); the Louisiana Cancer Research Consortium; the Louisiana Lions Eye Foundation, New Orleans, LA, USA; the Louisiana Vaccine Center and the South Louisiana Institute for Infectious Research sponsored by the Louisiana Board of Regents; Lions International USA.

\section{References}

[1] L. J. Al-Dujaili, P. P. Clerkin, C. Clement et al., "Ocular herpes simplex virus: how are latency, reactivation, recurrent disease and therapy interrelated?" Future Microbiology, vol. 6, no. 8, pp. 877-907, 2011.

[2] H. S. Toma, A. T. Murina, R. G. Areaux Jr. et al., "Ocular HSV-1 latency, reactivation and recurrent disease," Seminars in Ophthalmology, vol. 23, no. 4, pp. 249-273, 2008.

[3] E. R. Richter, J. K. Dias, J. E. Gilbert, and S. S. Atherton, "Distribution of herpes simplex virus type 1 and varicella zoster virus in ganglia of the human head and neck," Journal of Infectious Diseases, vol. 200, no. 12, pp. 1901-1906, 2009.

[4] D. E. Bustos and S. S. Atherton, "Detection of herpes simplex virus type 1 in human ciliary ganglia," Investigative Ophthalmology \& Visual Science, vol. 43, no. 7, pp. 22442249, 2002.

[5] Y. Shimomura, J. B. Dudley, L. P. Gongarosa, and J. M. Hill, "HSV-1 quantitation from rabbit neural tissues after epinephrine-induced reactivation," Investigative Ophthalmology \& Visual Science, vol. 26, no. 1, pp. 121-125, 1985.

[6] Y. Yamamoto and J. M. Hill, "HSV-1 recovery from ocular tissues after viral inoculation into the superior cervical ganglion," Investigative Ophthalmology \& Visual Science, vol. 27, no. 10, pp. 1447-1452, 1986.

[7] D. P. Kennedy, C. Clement, R. L. Arceneaux, P. S. Bhattacharjee, T. S. Huq, and J. M. Hill, "Ocular herpes simplex virus type 1: is the cornea a reservoir for viral latency or a fast pit stop?" Cornea, vol. 30, no. 3, pp. 251-259, 2011.

[8] J. M. Hill, M. A. Rayfield, and Y. Haruta, "Strain specificity of spontaneous and adrenergically induced HSV-1 ocular reactivation in latently infected rabbits," Current Eye Research, vol. 6, no. 1, pp. 91-97, 1987.

[9] B. S. Kwon, L. P. Gangarosa, K. D. Burch, J. deBack, and J. M. Hill, "Induction of ocular herpes simplex virus shedding by iontophoresis of epinephrine into rabbit cornea," Investigative Ophthalmology \& Visual Science, vol. 21, no. 3, pp. 442-449, 1981.

[10] Y. Haruta, L. J. Maguire, D. S. Rootman, and J. M. Hill, "Recurrent herpes simplex virus type 1 corneal epithelial lesions after radial keratotomy in the rabbit," Archives of Ophthalmology, vol. 105, no. 5, pp. 692-694, 1987.

[11] D. C. Bloom, G. B. Devi-Rao, J. M. Hill, J. G. Stevens, and E. K. Wagner, "Molecular analysis of herpes simplex virus type 1 during epinephrine- induced reactivation of latently infected rabbits in vivo," Journal of Virology, vol. 68, no. 3, pp. 12831292, 1994. 
[12] N. M. Sawtell, D. K. Poon, C. S. Tansky, and R. L. Thompson, "The latent herpes simplex virus type 1 genome copy number in individual neurons is virus strain specific and correlates with reactivation," Journal of Virology, vol. 72, no. 7, pp. 5343-5350, 1998.

[13] N. M. Sawtell, "Comprehensive quantification of herpes simplex virus latency at the single-cell level," Journal of Virology, vol. 71, no. 7, pp. 5423-5431, 1997.

[14] N. M. Sawtell and R. L. Thompson, "Herpes simplex virus type 1 latency-associated transcription unit promotes anatomical site-dependent establishment and reactivation from latency," Journal of Virology, vol. 66, no. 4, pp. $2157-$ 2169, 1992.

[15] Y. J. Gordon, K. A. Yates, F. S. Mah, and E. G. Romanowski, "The effects of Xalatan on the recovery of ocular herpes simplex virus type 1 (HSV-1) in the induced reactivation and spontaneous shedding rabbit models," Journal of Ocular Pharmacology and Therapeutics, vol. 19, no. 3, pp. 233-245, 2003.

[16] T. P. Margolis, F. L. Elfman, D. Leib et al., "Spontaneous reactivation of herpes simplex virus type 1 in latently infected murine sensory ganglia," Journal of Virology, vol. 81, no. 20, pp. 11069-11074, 2007.

[17] B. M. Gebhardt, E. D. Varnell, J. M. Hill, and H. E. Kaufman, "Animal models of ocular herpes simplex virus infection (rabbits, primates, mice)," in Handbook of Animal Models of Infection, O. Zak and M. Sande, Ed., pp. 919-926, Academic Press, London, UK, 1999.

[18] L. Caspary, B. Schindling, S. Dundarov, and D. Falke, "Infections of susceptible and resistant mouse strains with herpes simplex virus type 1 and 2," Archives of Virology, vol. 65, no. 3-4, pp. 219-227, 1980.

[19] R. D. Stulting, J. C. Kindle, and A. J. Nahmias, "Patterns of herpes simplex keratitis in inbred mice," Investigative Ophthalmology \& Visual Science, vol. 26, no. 10, pp. 13601367, 1985.

[20] A. A. Chentoufi, G. Dasgupta, N. D. Christensen et al., "A novel HLA (HLA-A*0201) transgenic rabbit model for preclinical evaluation of human CD8+ T cell epitope-based vaccines against ocular herpes," Journal of Immunology, vol. 184, no. 5, pp. 2561-2571, 2010.

[21] D. C. Bloom, "HSV-1 latency and the roles of the LATs," in Alpha Herpesviruses: Molecular and Cellular Biology, R. M. Sandri-Goldin, Ed., pp. 325-342, Caister Academic Press, Norwich, UK, 2006.

[22] G. C. Perng, S. M. Slanina, H. Ghiasi, A. B. Nesburn, and S. L. Wechsler, "The effect of latency-associated transcript on the herpes simplex virus type 1 latency-reactivation phenotype is mouse strain-dependent," Journal of General Virology, vol. 82, no. 5, pp. 1117-1122, 2001.

[23] R. L. Thompson and N. M. Sawtell, "The herpes simplex virus type 1 latency-associated transcript gene regulates the establishment of latency," Journal of Virology, vol. 71, no. 7, pp. 5432-5440, 1997.

[24] R. L. Thompson and N. M. Sawtell, "Herpes simplex virus type 1 latency-associated transcript gene promotes neuronal survival," Journal of Virology, vol. 75, no. 14, pp. 6660-6675, 2001.

[25] P. S. Bhattacharjee, D. M. Neumann, T. P. Foster et al., "Effect of human apolipoprotein E genotype on the pathogenesis of experimental ocular HSV-1," Experimental Eye Research, vol. 87, no. 2, pp. 122-130, 2008.

[26] J. M. Hill, P. S. Bhattacharjee, and D. M. Neumann, "Apolipoprotein E alleles can contribute to the pathogenesis of numerous clinical conditions including HSV-1 corneal disease," Experimental Eye Research, vol. 84, no. 5, pp. 801$811,2007$.

[27] J. S. Burgos, C. Ramirez, I. Sastre, M. J. Bullido, and F. Valdivieso, "Involvement of apolipoprotein $\mathrm{E}$ in the hematogenous route of herpes simplex virus type 1 to the central nervous system," Journal of Virology, vol. 76, no. 23, pp. 12394-12398, 2002.

[28] J. S. Burgos, C. Ramirez, I. Sastre, M. J. Bullido, and F. Valdivieso, "ApoE4 is more efficient than E3 in brain access by herpes simplex virus type I," NeuroReport, vol. 14, no. 14, pp. 1825-1827, 2003.

[29] P. S. Bhattacharjee, D. M. Neumann, D. Stark, H. W. Thompson, and J. M. Hill, "Apolipoprotein E modulates establishment of HSV-1 latency and survival in a mouse ocular model," Current Eye Research, vol. 31, no. 9, pp. 703708, 2006.

[30] T. J. Hill, D. A. Harbour, and W. A. Blyth, "Isolation of herpes simplex virus from the skin of clinically normal mice during latent infection," Journal of General Virology, vol. 47, no. 1, pp. 205-207, 1980.

[31] S. Z. Abghari and R. Stulting, "Recovery of herpes simplex virus from ocular tissues of latently infected inbred mice," Investigative Ophthalmology \& Visual Science, vol. 29, no. 2, pp. 239-243, 1988.

[32] D. L. Easty, C. Shimeld, C. M. Claoue, and M. Menage, "Herpes simplex virus isolation in chronic stromal keratitis: human and laboratory studies," Current Eye Research, vol. 6, no. 1, pp. 69-74, 1987.

[33] S. J. Allen, P. Hamrah, D. Gate et al., "The role of LAT in increased CD8+ T cell exhaustion in trigeminal ganglia of mice latently infected with herpes simplex virus 1," Journal of Virology, vol. 85, no. 9, pp. 4184-4197, 2011.

[34] S. J. Allen, K. R. Mott, M. Zandian, and H. Ghiasi, "Immunization with different viral antigens alters the pattern of $\mathrm{T}$ cell exhaustion and latency in herpes simplex virus type 1-infected mice," Journal of Virology, vol. 84, no. 23, pp. 12315-12324, 2010.

[35] P. B. Reddy, S. Sehrawat, A. Suryawannshi et al., "Influence of galectin-9/Tim-3 interaction on herpes simplex virus-1 latency," Journal of Immunology, vol. 187, no. 11, pp. 57455755, 2011.

[36] V. D. Menachery and D. A. Leib, "Control of herpes simplex virus replication is mediated through an interferon regulatory factor 3-dependent pathway," Journal of Virology, vol. 83, no. 23, pp. 12399-12406, 2009.

[37] R. J. Cohrs, D. M. Koelle, M. C. Schuette et al., "Asymptomatic alphaherpesvirus reactivation," in Herpesviridae: Viral Structure, Life Cycle and Infections, T. R. Gluckman, Ed., pp. 133-168, Nova Science, Hauppauge, NY, USA, 2009.

[38] M. Kumar, J. M. Hill, C. Clement, E. D. Varnell, H. W. Thompson, and H. E. Kaufman, "A double-blind placebocontrolled study to evaluate valacyclovir alone and with aspirin for asymptomatic HSV-1 DNA shedding in human tears and saliva," Investigative Ophthalmology \& Visual Science, vol. 50, no. 12, pp. 5601-5608, 2009.

[39] H. E. Kaufman, A. M. Azcuy, E. D. Varnell, G. D. Sloop, H. W. Thompson, and J. M. Hill, "HSV-1 DNA in tears and saliva of normal adults," Investigative Ophthalmology \& Visual Science, vol. 46, no. 1, pp. 241-247, 2005.

[40] E. J. Berman and J. M. Hill, "Spontaneous ocular shedding of HSV-1 in latently infected rabbits," Investigative Ophthalmology \& Visual Science, vol. 26, no. 4, pp. 587-590, 1985. 
[41] M. Kumar, H. E. Kaufman, C. Clement et al., "Effect of high versus low oral doses of valacyclovir on herpes simplex virus-1 DNA shedding into tears of latently infected rabbits," Investigative Ophthalmology \& Visual Science, vol. 51, no. 9, pp. 4703-4706, 2010.

[42] C. Shimeld, T. J. Hill, W. A. Blyth, and D. L. Easty, "Reactivation of latent infection and induction of recurrent herpetic eye disease in mice," Journal of General Virology, vol. 71, no. 2, pp. 397-404, 1990.

[43] L. T. Feldman, A. R. Ellison, C. C. Voytek, L. Yang, P. Krause, and T. P. Margolis, "Spontaneous molecular reactivation of herpes simplex virus type 1 latency in mice," Proceedings of the National Academy of Sciences of the United States of America, vol. 99, no. 2, pp. 978-983, 2002.

[44] D. E. Willey, M. D. Trousdale, and A. B. Nesburn, "Reactivation of murine latent HSV infection by epinephrine iontophoresis," Investigative Ophthalmology \& Visual Science, vol. 25, no. 8, pp. 945-950, 1984.

[45] B. M. Gebhardt and J. M. Hill, "T lymphocytes in the trigeminal ganglia of rabbits during corneal HSV infection," Investigative Ophthalmology \& Visual Science, vol. 29, no. 11, pp. 1683-1691, 1988.

[46] N. M. Sawtell, "Quantitative analysis of herpes simplex virus reactivation in vivo demonstrates that reactivation in the nervous system is not inhibited at early times postinoculation," Journal of Virology, vol. 77, no. 7, pp. 4127-4138, 2003.

[47] G. C. Perng, E. C. Dunkel, P. A. Geary et al., "The latency-associated transcript gene of herpes simplex virus type 1 (HSV-1) is required for efficient in vivo spontaneous reactivation of HSV-1 from latency," Journal of Virology, vol. 68, no. 12, pp. 8045-8055, 1994.

[48] G. C. Perng, D. Esmaili, S. M. Slanina et al., "Three herpes simplex virus type 1 latency-associated transcript mutants with distinct and asymmetric effects on virulence in mice compared with rabbits," Journal of Virology, vol. 75, no. 19, pp. 9018-9028, 2001.

[49] S. D. Cook, M. J. Paveloff, J. J. Doucet, A. J. Cottingham, F. Sedarati, and J. M. Hill, "Ocular herpes simplex virus reactivation in mice latently infected with latency-associated transcript mutants," Investigative Ophthalmology \& Visual Science, vol. 32, no. 5, pp. 1558-1561, 1991.

[50] D. M. Neumann, P. S. Bhattacharjee, N. V. Giordani, D. C. Bloom, and J. M. Hill, "In vivo changes in the patterns of chromatin structure associated with the latent herpes simplex virus type 1 genome in mouse trigeminal ganglia can be detected at early times after butyrate treatment," Journal of Virology, vol. 81, no. 23, pp. 13248-13253, 2007.

[51] D. M. Neumann, P. S. Bhattacharjee, and J. M. Hill, "Sodium butyrate: a chemical inducer of in vivo reactivation of herpes simplex virus type 1 in the ocular mouse model," Journal of Virology, vol. 81, no. 11, pp. 6106-6110, 2007.

[52] C. Clement, P. S. Bhattacharjee, M. Kumar, H. W. Thompson, J. M. Hill, and T. P. Foster, "Upregulation of mouse genes in HSV-1 latent TG after butyrate treatment implicates the multiple roles of the LAT-ICP0 locus," Investigative Ophthalmology \& Visual Science, vol. 52, no. 3, pp. 1770$1779,2011$.

[53] N. M. Sawtell and R. L. Thompson, "Rapid in vivo reactivation of herpes simplex virus in latently infected murine ganglionic neurons after transient hyperthermia," Journal of Virology, vol. 66, no. 4, pp. 2150-2156, 1992.

[54] C. Clement, P. S. Bhattacharjee, H. E. Kaufman, and J. M. Hill, "Heat-induced reactivation of HSV-1 in latent mice: upregulation in the TG of CD83 and other immune response genes and their LAT-ICP0 locus," Investigative Ophthalmology \& Visual Science, vol. 50, no. 6, pp. 28552861, 2009.

[55] H. E. Kaufman, E. D. Varnell, and H. W. Thompson, "Latanoprost increases the severity and recurrence of herpetic keratitis in the rabbit," American Journal of Ophthalmology, vol. 127, no. 5, pp. 531-536, 1999.

[56] B. M. Gebhardt, E. D. Varnell, and H. E. Kaufman, "Acetylsalicylic acid reduces viral shedding induced by thermal stress," Current Eye Research, vol. 29, no. 2-3, pp. 119-125, 2004.

[57] M. E. Marquart, X. Zheng, R. K. Tran, H. W. Thompson, D. C. Bloom, and J. M. Hill, "A cAMP response element within the latency-associated transcript promoter of HSV-1 facilitates induced ocular reactivation in a mouse hyperthermia model," Virology, vol. 284, no. 1, pp. 62-69, 2001.

[58] S. Higaki, K. Watanabe, M. Itahashi, and Y. Shimomura, "Cyclooxygenase (COX)-inhibiting drug reduces HSV-1 reactivation in the mouse eye model," Current Eye Research, vol. 34, no. 3, pp. 171-176, 2009.

[59] L. Corey, A. Wald, R. Patel et al., "Once-daily valacyclovir to reduce the risk of transmission of genital herpes," The New England Journal of Medicine, vol. 350, no. 1, pp. 11-20, 2004.

[60] J. T. Schiffer, A. Magaret, S. Selke, L. Corey, and A. Wald, "Detailed analysis of mucosal herpes simplex virus2 replication kinetics with and without antiviral therapy," Journal of Antimicrobial Chemotherapy, vol. 66, no. 11, pp. 2593-2600, 2011.

[61] B. M. Gebhardt, H. E. Kaufman, and J. M. Hill, "Effect of acyclovir on thermal stress-induced herpesvirus reactivation," Current Eye Research, vol. 29, no. 2-3, pp. 137-144, 2004.

[62] B. M. Gebhardt and H. E. Kaufman, "Propranolol suppresses reactivation of herpesvirus," Antiviral Research, vol. 27, no. 3, pp. 255-261, 1995.

[63] A. B. Nesburn, M. L. Cook, and J. G. Stevens, "Latent herpes simplex virus. Isolation from rabbit trigeminal ganglia between episodes of recurrent ocular infection," Archives of Ophthalmology, vol. 88, no. 4, pp. 412-417, 1972.

[64] D. C. Bloom, J. G. Stevens, J. M. Hill, and R. K. Tran, "Mutagenesis of a cAMP response element within the latency-associated transcript promoter of HSV-1 reduces adrenergic reactivation," Virology, vol. 236, no. 1, pp. 202207, 1997.

[65] G. C. Perng, S. M. Slanina, A. Yukht, H. Ghiasi, A. B. Nesburn, and S. L. Wechsler, "The latency-associated transcript gene enhances establishment of herpes simplex virus type 1 latency in rabbits," Journal of Virology, vol. 74, no. 4, pp. 1885-1891, 2000.

[66] C. Clement, M. P. Popp, D. C. Bloom et al., "Microarray analysis of host gene expression for comparison between naïve and HSV-1 latent rabbit trigeminal ganglia," Molecular Vision, vol. 14, pp. 1209-1221, 2008.

[67] P. R. Laibson and S. Kibrick, "Recurrence of herpes simplex virus in rabbit eyes: results of a three-year study," Investigative ophthalmology, vol. 8, no. 3, pp. 346-350, 1969.

[68] A. B. Nesburn, J. H. Elliott, and H. M. Leibowitz, "Spontaneous reactivation of experimental herpes simplex keratitis in rabbits," Archives of Ophthalmology, vol. 78, no. 4, pp. 523529, 1967.

[69] H. E. Kaufman and C. Heidelberger, "Therapeutic antiviral action of 5-trifluoromethyl-2'-deoxyuridine in herpes simplex keratitis," Science, vol. 145, no. 3632, pp. 585-586, 1964.

[70] H. E. Kaufman, "The first effective antiviral," in The Search for Antiviral Drugs, J. Adams and V. J. Merluzzi, Eds., pp. 121, Birkhauser, Boston, Mass, USA, 1993. 
[71] Y. Shimomura, L. P. Gangarosa Sr., M. Kataoka, and J. M. Hill, "HSV-1 shedding by iontophoresis of 6hydroxydopamine followed by topical epinephrine," Investigative Ophthalmology \& Visual Science, vol. 24, no. 12, pp. 1588-1594, 1983.

[72] J. M. Hill, Y. Shimomura, B. S. Kwon, and L. P. Gangarosa Sr., "Iontophoresis of epinephrine isomers to rabbit eyes induced HSV-1 ocular shedding," Investigative Ophthalmology \& Visual Science, vol. 26, no. 9, pp. 1299-1303, 1985.

[73] B. S. Kwon, L. P. Gangarosa, K. Green, and J. M. Hill, "Kinetics of ocular herpes simplex virus shedding induced by epinephrine iontophoresis," Investigative Ophthalmology \& Visual Science, vol. 22, no. 6, pp. 818-821, 1982.

[74] J. M. Hill, B. S. Kwon, Y. Shimomura, G. L. Colborn, F. Yaghmai, and L. P. Gangarosa, "Herpes simplex virus recovery in neural tissues after ocular HSV shedding induced by epinephrine iontophoresis to the rabbit cornea," Investigative Ophthalmology \& Visual Science, vol. 24, no. 2, pp. 243-247, 1983.

[75] P. R. Laibson and S. Kibrick, "Reactivation of herpetic keratitis by epinephrine in rabbit," Archives of Ophthalmology, vol. 75, no. 2, pp. 254-260, 1966.

[76] P. R. Laibson and S. Kibrick, "Reactivation of herpetic keratitis in rabbit. II. Repeated reactivations in the same host," Archives of Ophthalmology, vol. 77, no. 2, pp. 244-248, 1967.

[77] A. B. Nesburn, M. T. Green, M. Radnoti, and B. Walker, "Reliable in vivo model for latent herpes simplex virus reactivation with peripheral virus shedding," Infection and Immunity, vol. 15, no. 3, pp. 772-775, 1977.

[78] A. B. Nesburn, R. Dickinson, and M. Radnoti, "The effect of trigeminal nerve and ganglion manipulation on recurrence of ocular herpes simplex in rabbits," Investigative Ophthalmology, vol. 15, no. 9, pp. 726-731, 1976.

[79] M. Green, J. Rosborough, and E. Dunkel, "In vivo reactivation of herpes simplex virus in rabbit trigeminal ganglia: electrode model," Infection and Immunity, vol. 34, no. 1, pp. 69-74, 1981.

[80] H. E. Kaufman, E. D. Varnell, B. M. Gebhardt, H. W. Thompson, and J. M. Hill, "Propanolol suppression of ocular HSV-1 recurrence and associated corneal lesions following spontaneous reactivation in the rabbit," Current Eye Research, vol. 15, no. 6, pp. 680-684, 1996.

[81] J. M. Hill, Y. Shimomura, J. B. Dudley et al., "Timolol induces HSV-1 ocular shedding in the latently infected rabbit," Investigative Ophthalmology \& Visual Science, vol. 28, no. 3, pp. 585-590, 1987.

[82] H. H. Garza Jr. and J. M. Hill, "Effect of a beta-adrenergic antagonist, propranolol, on induced HSV-1 ocular recurrence in latently infected rabbits," Current Eye Research, vol. 16, no. 5, pp. 453-458, 1997.

[83] C. F. Beyer, M. Q. Arens, J. M. Hill, B. T. Rose, G. A. Hill, and D. T. C. Lin, "Penetrating keratoplasty in rabbits induces latent HSV-1 reactivation when corticosteroids are used," Current Eye Research, vol. 8, no. 12, pp. 1323-1329, 1989.

[84] C. F. Beyer, J. M. Hill, J. Reidy, and R. W. Beuerman, “Corneal nerve disruption reactivates virus in rabbits latently infected with HSV-1," Investigative Ophthalmology \& Visual Science, vol. 31, no. 5, pp. 925-932, 1990.

[85] C. F. Beyer, D. J. Tepper, and J. M. Hill, "Cryogenic induced ocular HSV-1 reactivation is enhanced by an inhibitor of the lipoxygenase pathway," Current Eye Research, vol. 8, no. 12, pp. 1287-1292, 1989.
[86] M. E. Myles, C. Alack, P. M. Manino et al., "Nicotine applied by transdermal patch induced HSV-1 reactivation and ocular shedding in latently infected rabbits," Journal of Ocular Pharmacology and Therapeutics, vol. 19, no. 2, pp. 121-133, 2003.

[87] J. M. Hill, H. H. Garza, M. F. Helmy et al., "Nerve growth factor antibody stimulates reactivation of ocular herpes simplex virus type 1 in latently infected rabbits," Journal of NeuroVirology, vol. 3, no. 3, pp. 206-211, 1997.

[88] Y. Haruta, D. S. Rootman, L. Xie, A. Kiritoshi, and J. M. Hill, "Recurrent HSV-1 corneal lesions in rabbits induced by cyclophosphamide and dexamethasone," Investigative Ophthalmology \& Visual Science, vol. 30, no. 3, pp. 371-376, 1989.

[89] M. E. Myles, A. Azcuy, N. T. Nguyen et al., "Bupropion (Zyban, Wellbutrin) inhibits nicotine-induced viral reactivation in herpes simplex virus type 1 latent rabbits," Journal of Pharmacology and Experimental Therapeutics, vol. 311, no. 2, pp. 640-644, 2004.

[90] Y. J. Gordon, E. Romanowski, J. Harwick, J. Berman, L. Olsakovsky, and T. Araullo-Cruz, "The effect of alpha blockade on iontophoresis-induced ocular shedding of latent HSV-1 W in different host animals," Current Eye Research, vol. 9, no. 10, pp. 1007-1014, 1990.

[91] J. M. Hill, R. Wen, and W. P. Halford, "Pathogenesis and molecular biology of ocular HSV in the rabbit," in Herpes simplex Virus Protocols, M. S. Brown and A. R. MacLean, Eds., pp. 291-315, Humana Press, 1998.

[92] B. A. Richardson and J. Overbaugh, "Basic statistical considerations in virological experiments," Journal of Virology, vol. 79, no. 2, pp. 669-676, 2005.

[93] A. Agresti, Categorical Data Analysis, Wiley, New York, NY, USA, 1990.

[94] G. Casella and R. L. Berger, Statistical Inference, Thomson Learning, Pacific Grove, Calif, USA, 2002.

[95] R. A. Fisher, "On the interpretation of $x^{2}$ from contingency tables, and the calculations of P," Journal of Royal Statistical Society, vol. 85, no. 1, pp. 87-94, 1922.

[96] A. Agresti, "A survey of exact inference for contingency tables," Statistical Science, vol. 7, no. 1, pp. 131-153, 1992.

[97] R. Mera, H. W. Thompson, and C. Prasad, "Analysis of data that is in the form of categories: Part I: Interpretation, Chisquare, odds ratio and sample size," Nutritional Neuroscience, vol. 2, no. 5, pp. 369-374, 1999.

[98] R. Mera, H. W. Thompson, and C. Prasad, "Analysis of data that is in the form of categories Part II: Beyond the $2 * 2$ contingency table -partitioning Chi-square tests," Nutritional Neuroscience, vol. 3, no. 2, pp. 143-149, 2000.

[99] P. McCullagh and J. A. Nelder, Generalized Linear Models, Chapman and Hall, New York, NY, USA, 1989.

[100] K. Y. Liang and S. L. Zeger, "Longitudinal data analysis using generalized linear models," Biometrika, vol. 73, no. 1, pp. 1322, 1986.

[101] E. Demidenko, Mixed Models: Theory and Applications, Wiley-Interscience, Hoboken, NJ, USA, 2004.

[102] W. P. Halford, B. M. Gebhardt, and D. J. J. Carr, "Mechanisms of herpes simplex virus type 1 reactivation," Journal of Virology, vol. 70, no. 8, pp. 5051-5060, 1996.

[103] T. J. Pasieka, L. Collins, M. A. O’Connor et al., "Bioluminescent imaging reveals divergent viral pathogenesis in two strains of Stat1-deficient mice, and in $\alpha \beta \gamma$ interferon receptor-deficient mice," PLoS ONE, vol. 6, no. 9, Article ID e24018, 2011.

[104] M. P. Vitek, C. M. Brown, and C. A. Colton, "APOE genotype-specific differences in the innate immune 
response," Neurobiology of Aging, vol. 30, no. 9, pp. 1350-1360, 2009.

[105] T. J. Pasieka, B. Lu, and D. A. Leib, "Enhanced pathogenesis of an attenuated herpes simplex virus for mice lacking Stat1," Journal of Virology, vol. 82, no. 12, pp. 6052-6055, 2008.

[106] B. Kim, P. P. Sarangi, A. K. Azkur, S. D. Kaistha, and B. T. Rouse, "Enhanced viral immunoinflammatory lesions in mice lacking IL-23 responses," Microbes and Infection, vol. 10, no. 3, pp. 302-312, 2008.

[107] D. J. Lenschow, C. Lai, N. Frias-Staheli et al., "IFN-stimulated gene 15 functions as a critical antiviral molecule against influenza, herpes, and Sindbis viruses," Proceedings of the National Academy of Sciences of the United States of America, vol. 104, no. 4, pp. 1371-1376, 2007.

[108] K. Banerjee, P. S. Biswas, and B. T. Rouse, "Role of Stat4mediated signal transduction events in the generation of aggressor CD4+ T cells in herpetic stromal keratitis pathogenesis," Journal of Interferon and Cytokine Research, vol. 27, no. 1, pp. 65-75, 2007.

[109] P. S. Biswas, K. Banerjee, B. Kim, and B. T. Rouse, "Mice transgenic for IL-1 receptor antagonist protein are resistant to herpetic stromal keratitis: possible role for IL-1 in herpetic stromal keratitis pathogenesis," Journal of Immunology, vol. 172, no. 6, pp. 3736-3744, 2004.

[110] W. P. Halford, C. Weisend, J. Grace et al., "ICP0 antagonizes Stat 1-dependent repression of herpes simplex virus: implications for the regulation of viral latency," Virology Journal, vol. 3, article 44, 2006.

[111] S. D. Haenchen, J. A. Utter, A. M. Bayless, R. T. Dobrowsky, and D. J. Davido, "Role of a cdk5-associated protein, p35, in herpes simplex virus type 1 replication in vivo," Journal of NeuroVirology, vol. 16, no. 5, pp. 405-409, 2010.

[112] K. A. Laycock, S. F. Lee, R. H. Brady, and J. S. Pepose, "Characterization of a murine model of recurrent herpes simplex viral keratitis induced by ultraviolet B radiation," Investigative Ophthalmology \& Visual Science, vol. 32, no. 10, pp. 2741-2746, 1991.

[113] J. M. Pesola, J. Zhu, D. M. Knipe, and D. M. Coen, "Herpes simplex virus 1 immediate-early and early gene expression during reactivation from latency under conditions that prevent infectious virus production," Journal of Virology, vol. 79, no. 23, pp. 14516-14525, 2005.

[114] J. D. Kriesel, B. M. Gebhardt, J. M. Hill et al., "Antiinterleukin-6 antibodies inhibit herpes simplex virus reactivation," Journal of Infectious Diseases, vol. 175, no. 4, pp. 821827, 1997.

[115] B. M. Gebhardt, E. D. Varnell, and H. E. Kaufman, "Inhibition of cyclooxygenase 2 synthesis suppresses herpes simplex virus type 1 reactivation," Journal of Ocular Pharmacology and Therapeutics, vol. 21, no. 2, pp. 114-120, 2005.

[116] J. M. Hill, Y. Haruta, and D. S. Rootman, "Adrenergically induced recurrent HSV-1 corneal epithelial lesions," Current Eye Research, vol. 6, no. 8, pp. 1065-1071, 1987.

[117] Y. Haruta, D. S. Rootman, and J. M. Hill, "Recurrent HSV1 corneal epithelial lesions induced by timolol iontophoresis in latently infected rabbits," Investigative Ophthalmology \& Visual Science, vol. 29, no. 3, pp. 387-392, 1988. 


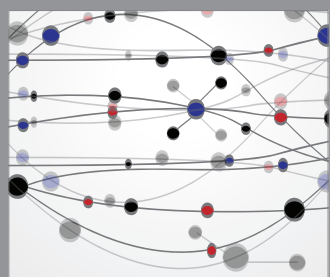

The Scientific World Journal
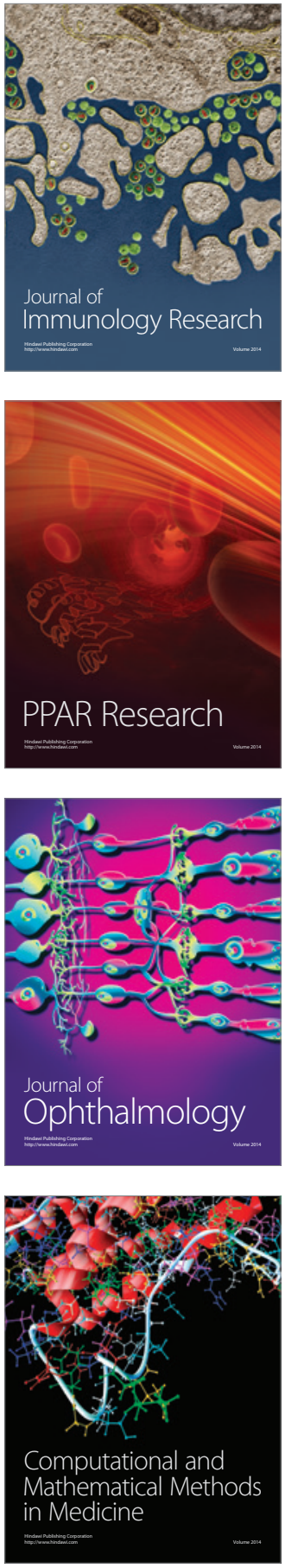

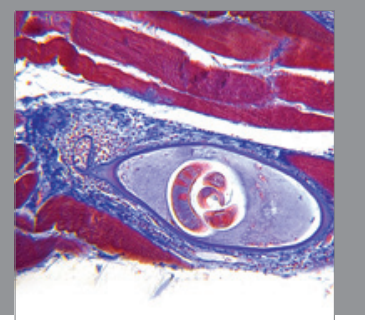

Gastroenterology

Research and Practice
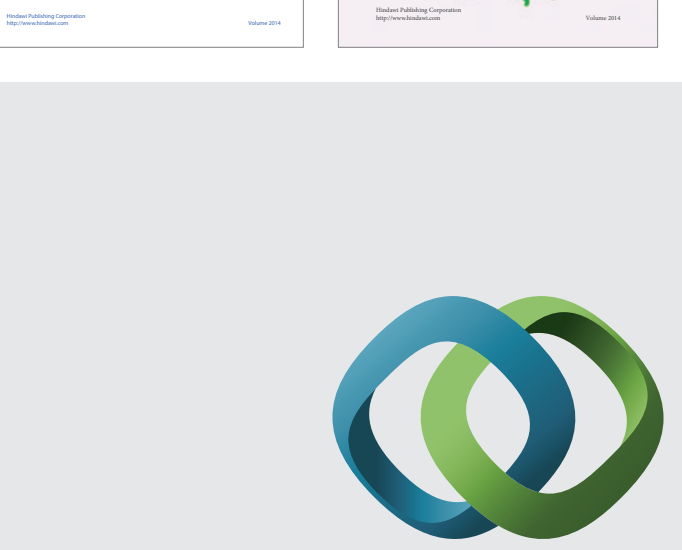

\section{Hindawi}

Submit your manuscripts at

http://www.hindawi.com
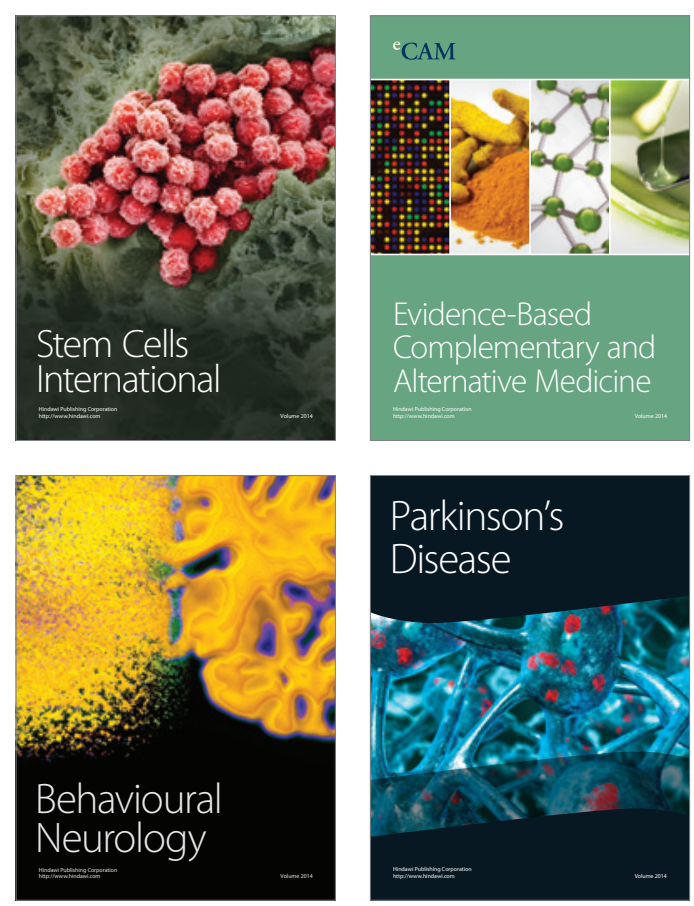

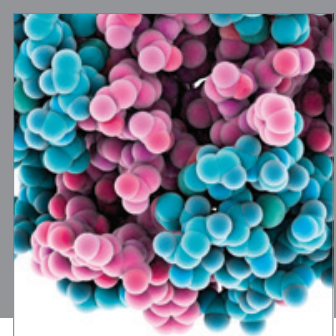

Journal of
Diabetes Research

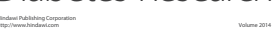

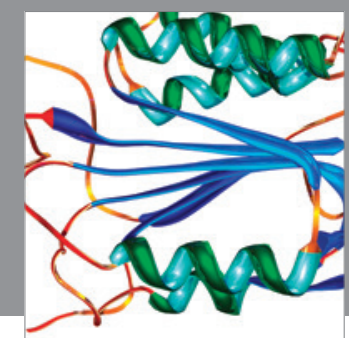

Disease Markers
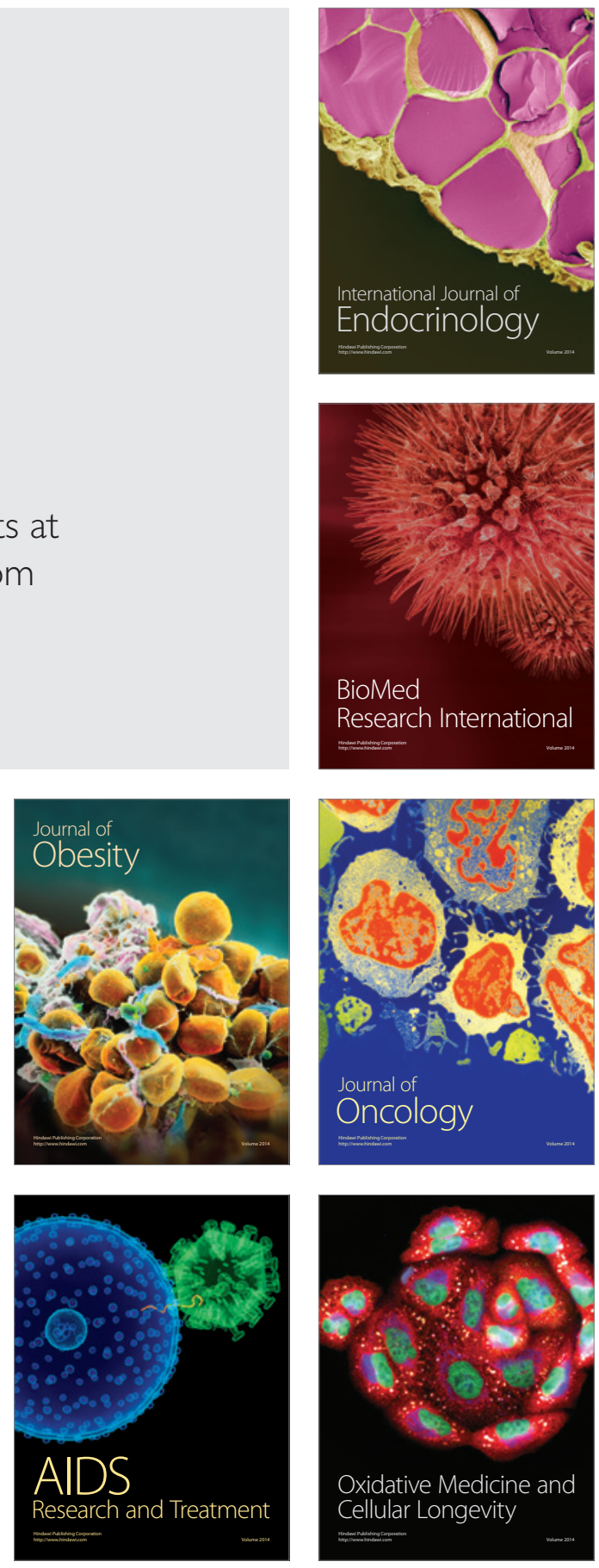